\title{
ثالثًا : الحلديثُ وعلومه
}

-รพ9- 


\section{رواية سعد بن أبي وقتاص هويندغن}

لحديث: "عجبت للمؤمن إن أصابه خحيز مد الله وشكره"

تخويجاً ونقداً

\section{إعداد الباحثة}

$$
\text { حليمة عبدالله زيد الشيخي الشمرابي }
$$

طالبة في مرحلة الدكتوراة بكلية الدعوة وأصول الدين في قسم الكتاب والسنة تخصص الحديث وعلومه بجامعة أم القرى في المملكة العربية السعودية 


\section{المقدمة}

إن الحمد الله، نحمده، ونستعينه، ونستغفره، ونعوذ بالله من شرور أنفسنا وسيئات

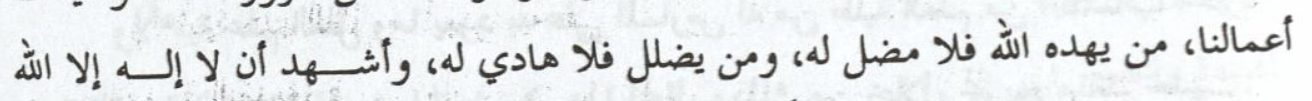
وحده لاشريك له وأشهد أن محمدأ عبده ورسوله. أما بعد: فإن علوم السنة من أشرف العلوم وأجلْها؛ لتعلقها بالــــصدر الثــاني للتـشـريع

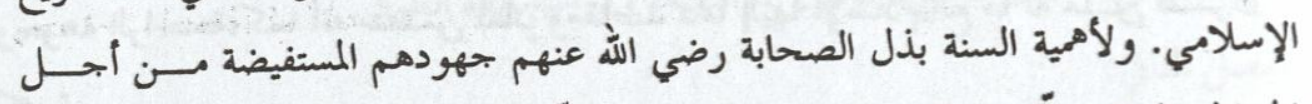

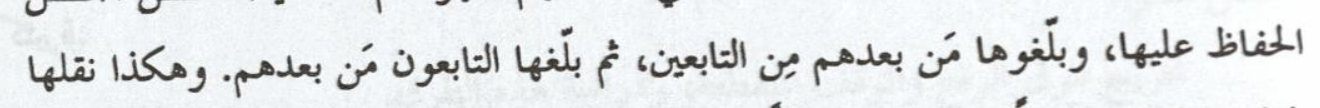

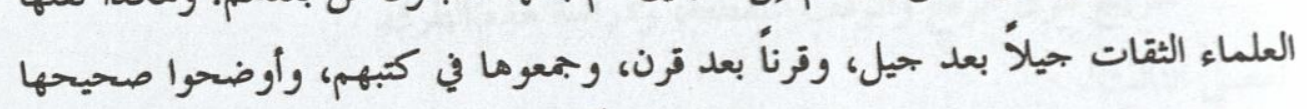

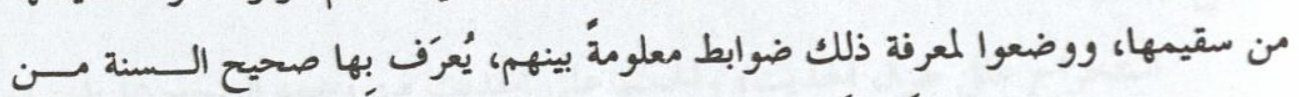

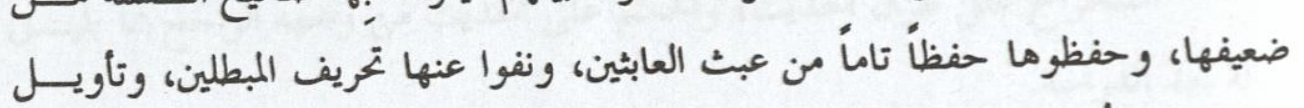

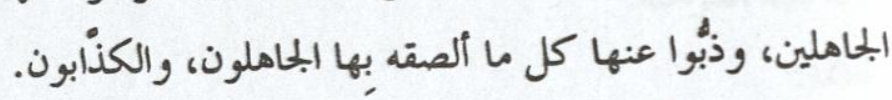

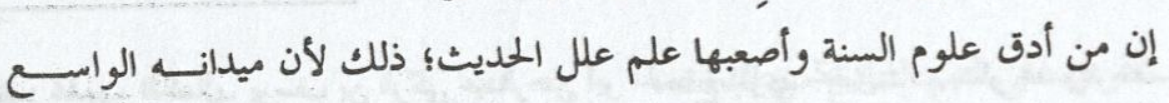

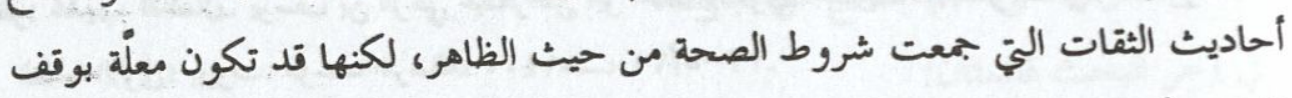

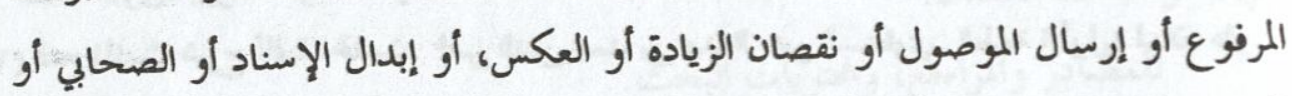

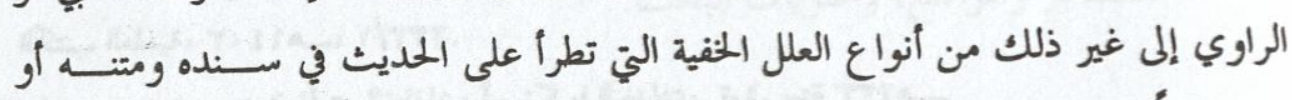

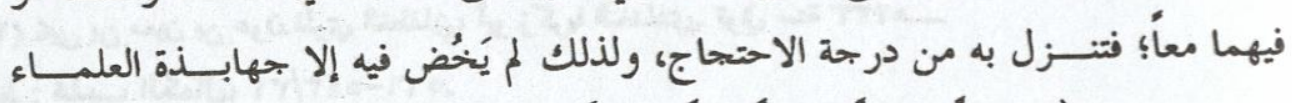

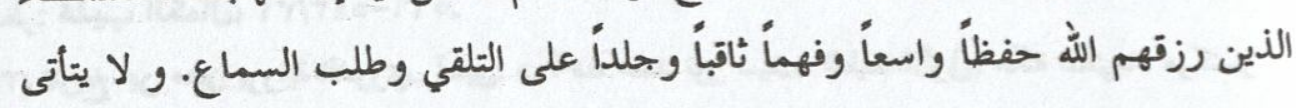
معرفة علة الحديث إلا بتخريجه وجمع طرقه والمقارنة بينها. قال علي بن المديني (1): (الباب إذا لم بتمع طرقه لم يتبين خطؤه) (1).

(1) علي بن عبد الله بن جعفر بن بنيح السعدي، أبو المسن بن المديني. توفي سنة عrامهـ.-

\section{ملنحص البحث}

يهتم البحث بجمع وحصر وتخريج طرق الحديث عن الصحابي الجليل سعد

ابن أبي وقاص رضي الله عنه، بجميع أنواعها الموصول، والمنقطع، والمرفوع، والموقوف، ثم دراستها ونقدها. وقد خلص إلى ترجيح طرق الرفع الموصولة عن

سعد بن أبي وقاص رضي الله عنه، وما عداها طرقّ مُعللة، وحكم على ما رجحه من طرق بأنه حسن الإسناد صحيح المتن. 


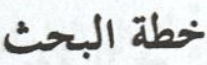

يتكون البحث إجمالاً من: مقدمة، وثلالة فصول، وخاتمة، وفهارس.

وتفصيلها كالآني:

المقدمة وتتضمن:

أهية الموضوع، وأسباب اختياره.

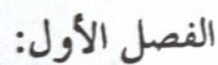

تخريج طرق الرفع والوقف الموصولة، ودراسة هذه الطرق.

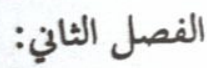

تخريج طرق الرفع والوقف المنقطعة، ودراسة هذه الطرق.

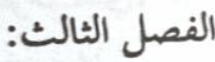

استخراج علل طرق الحديث، والمكم على الحديث من وجهه الراجح .ما يليــن

بحاله بعد الدراسة.

تحتوي على أهم النتائج من البحث.

وفي آخر البحث قائمتان: - المان

للمصادر والمراجع، ولمحتويات البحث.
وقال ابن معين"): (لو لم نكتب الحديث من ثلأين وجهاً ما عقلناه) (")، وزاد أبو

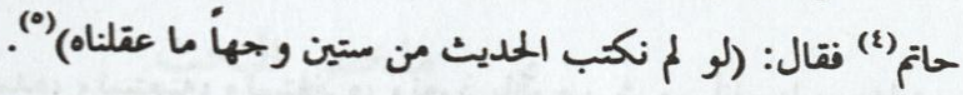

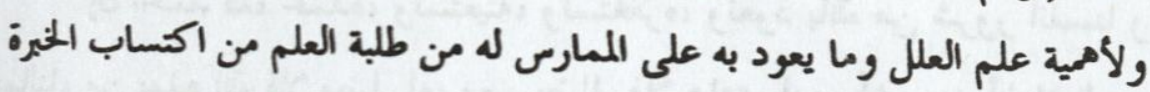

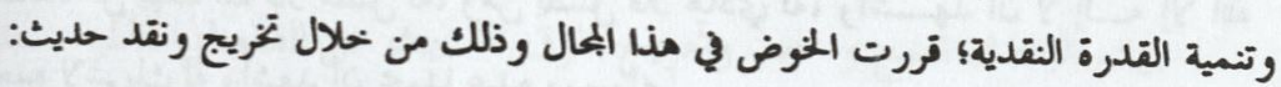

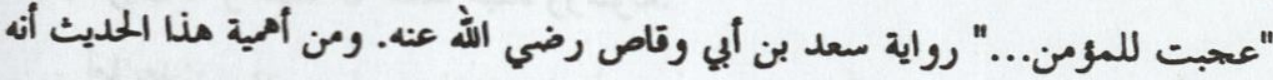

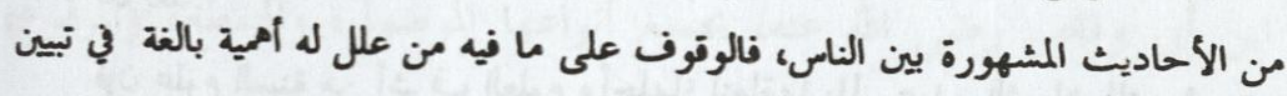

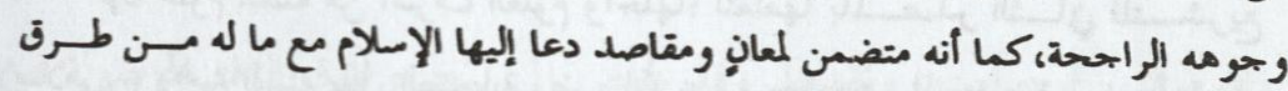

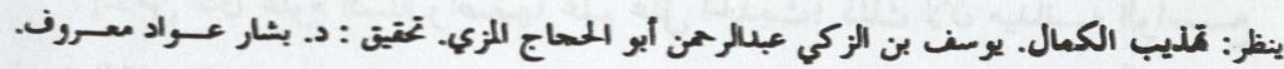

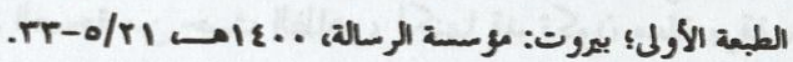

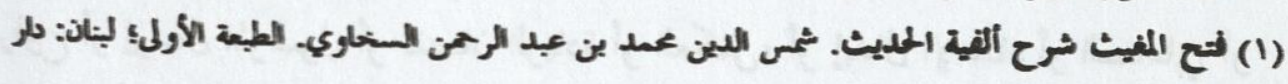

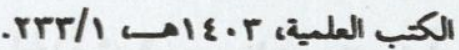

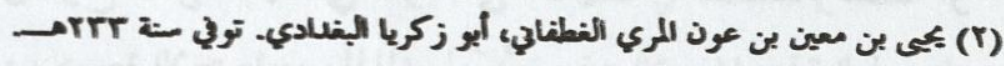

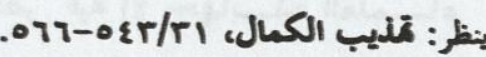

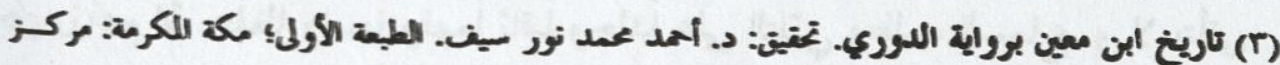

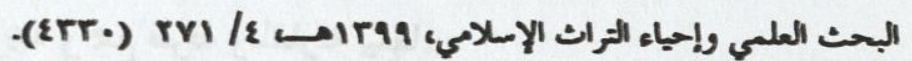

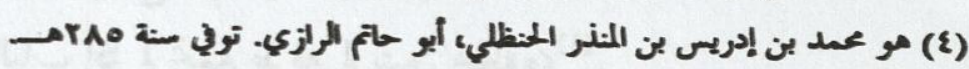

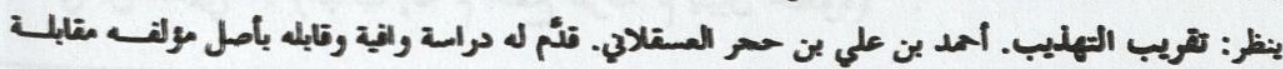

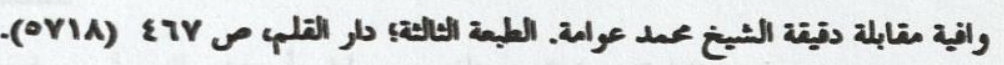

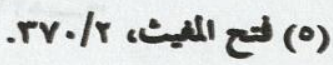


11 ا. أترجم لرجال الطرق، ذاكرة" أقوال العلماء في حال الرجال، ومعتمدةُ ما ذكره الحافظ ابن حجر في حال رواتها في تقريب التهذيب إن كان الراوي مختلفاً فيه. r ا. . أذكر علل الطرق، ثم أرجح الرواية الراجحة. ז ا. . أحكم على الرواية الراجحة ذاكرة ما قال العلماء في حكمها. ع ا. أترجم للأعلام الواردة أسماؤهم في البحث.

\section{طريقة البحث}

ا. أختار الرواية الريانة الجامعة لجميع ألفاظ المتن فأجعلها الرواية الأصل التي أقارن عليها الأسانيد.

r. أذكر في أعلى الصحيفة الرواية المختارة، فأذكر إسنادها لمقارنة بقيـــة أسـانيد الطرق عليه.

r. إن اتفق أكثر من كتاب في تخريج الرواية المختارة قدمت من كان إسناده أعلى، فأقدم مثلأ رواية وكيع على أحمد والضياء.

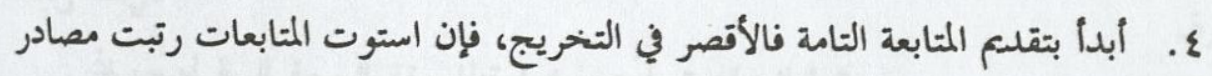

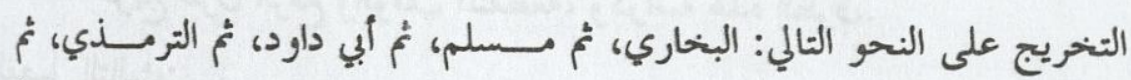
النسائي في البحتى، ثم ابن ماجة، ثم مسند أحمد، وبعدها أرتب المصادر تأريخيـان حسب وفاة المصنف. ه. أخرج الروايات من كتب السنة قدر المستطاع بعد تصنيفها، فأخرج في الفــصل

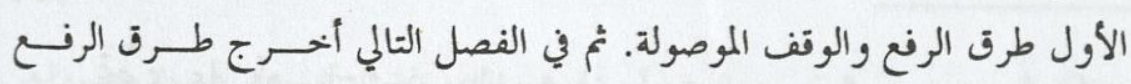
والوقف المنقطعة. 7. أقارن المتون باللفظ المطلوب فما كان بلفظه قلت بمثله، وما كان باختلاف يسير قلت بنحوه، وما كان باختلاف كبير قلت بمعناه. V. أشَجرِ لطرق الرواية، وأتبع ما يخص كلاً منها هما. 1. أبين الغريب من الألفاظ بالرجوع لكتب الغريب، وكتب اللغة. 9. أضبط المُشكِل من الألفاظ، كما أضبط الأسماء والأنساب. • 1.

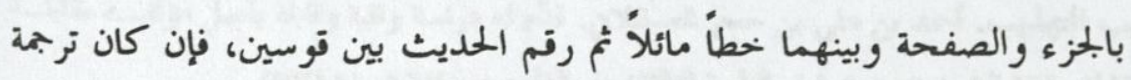
لراوي فرقم الترجة بين القوسين. 


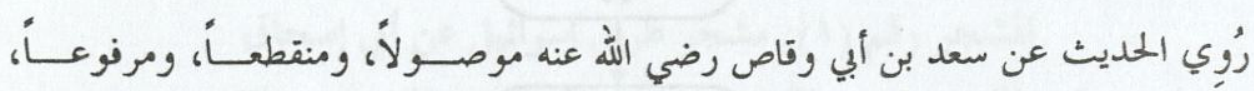

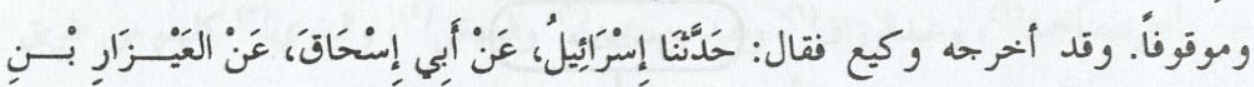

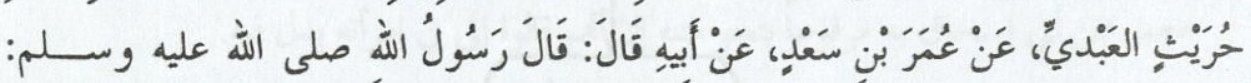

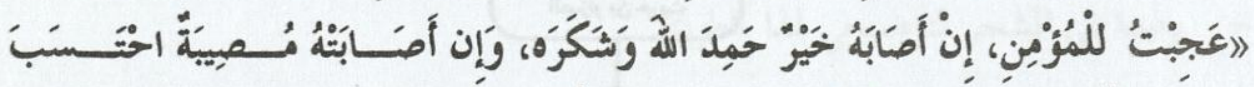

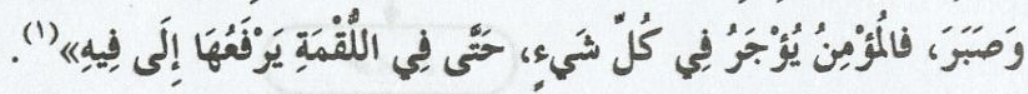

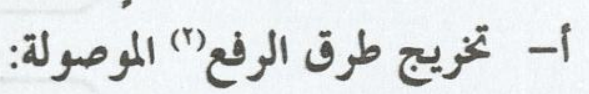

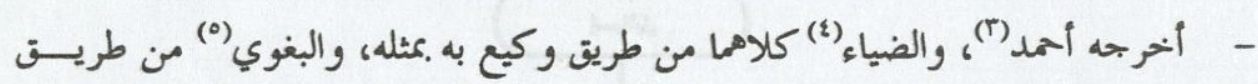
عبيدالله بن موسى عن إسرائيل به بنحوه. - وفيما يلي المشتر التوضيحي لهذا الطريق:

(1) كتاب الزهد. وكيع بن الجراح. تحقيق عبدالرحمن بن عبدالجبار الفريوائي. المدينة المنورة: مكتبة الــدار،

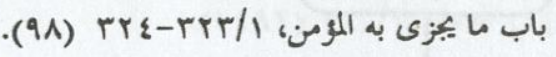

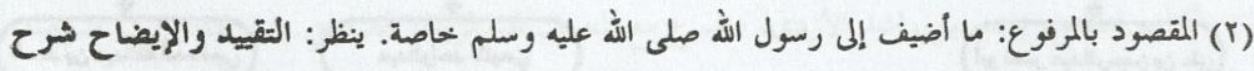

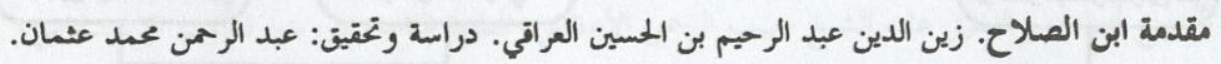

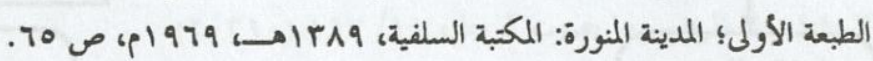

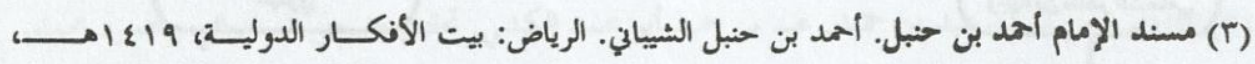
. (l0V0) $114 \mathrm{r} / 1$

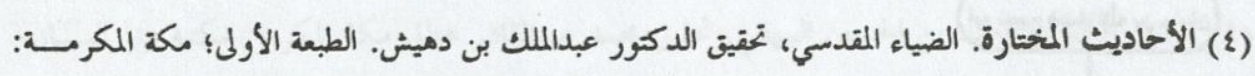

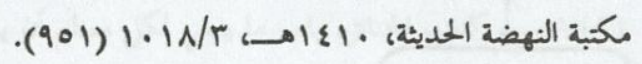

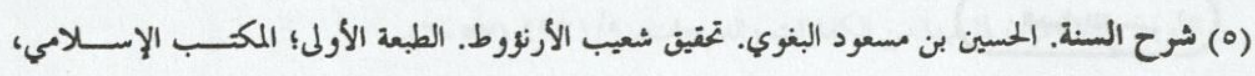

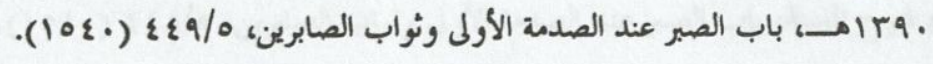




\section{المشجر رقم (1): مشجّر طريق إسرائيل عن أبي إسحاق (1) (1) وعداق}

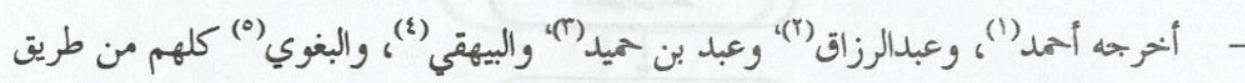

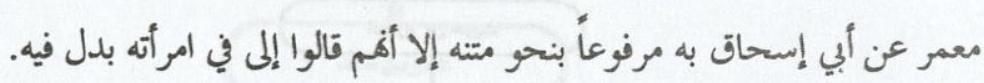
- م وفيما يلي المشجر التوضيحي لهذا الطريق:

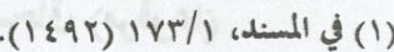

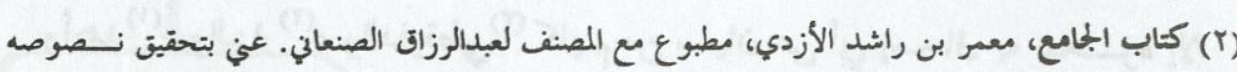

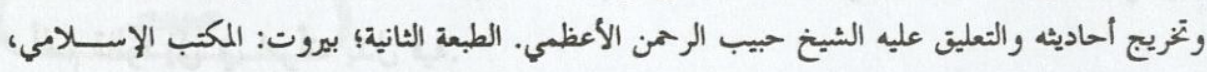

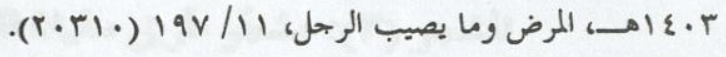

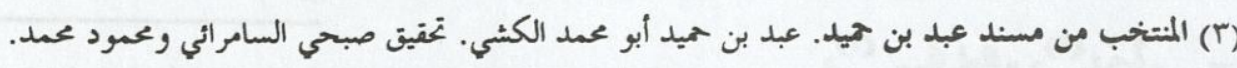

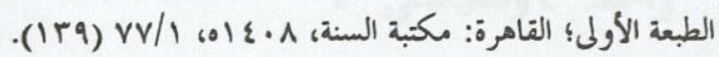

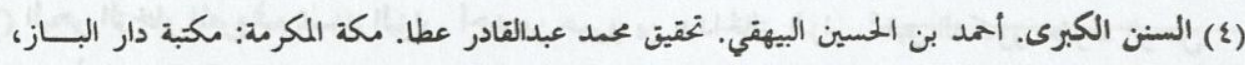

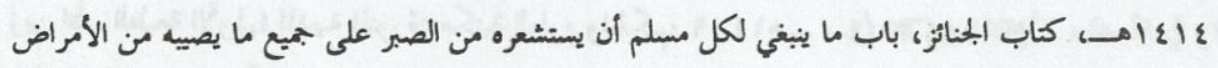

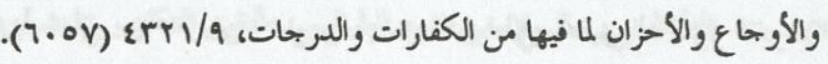

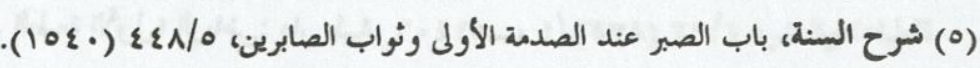

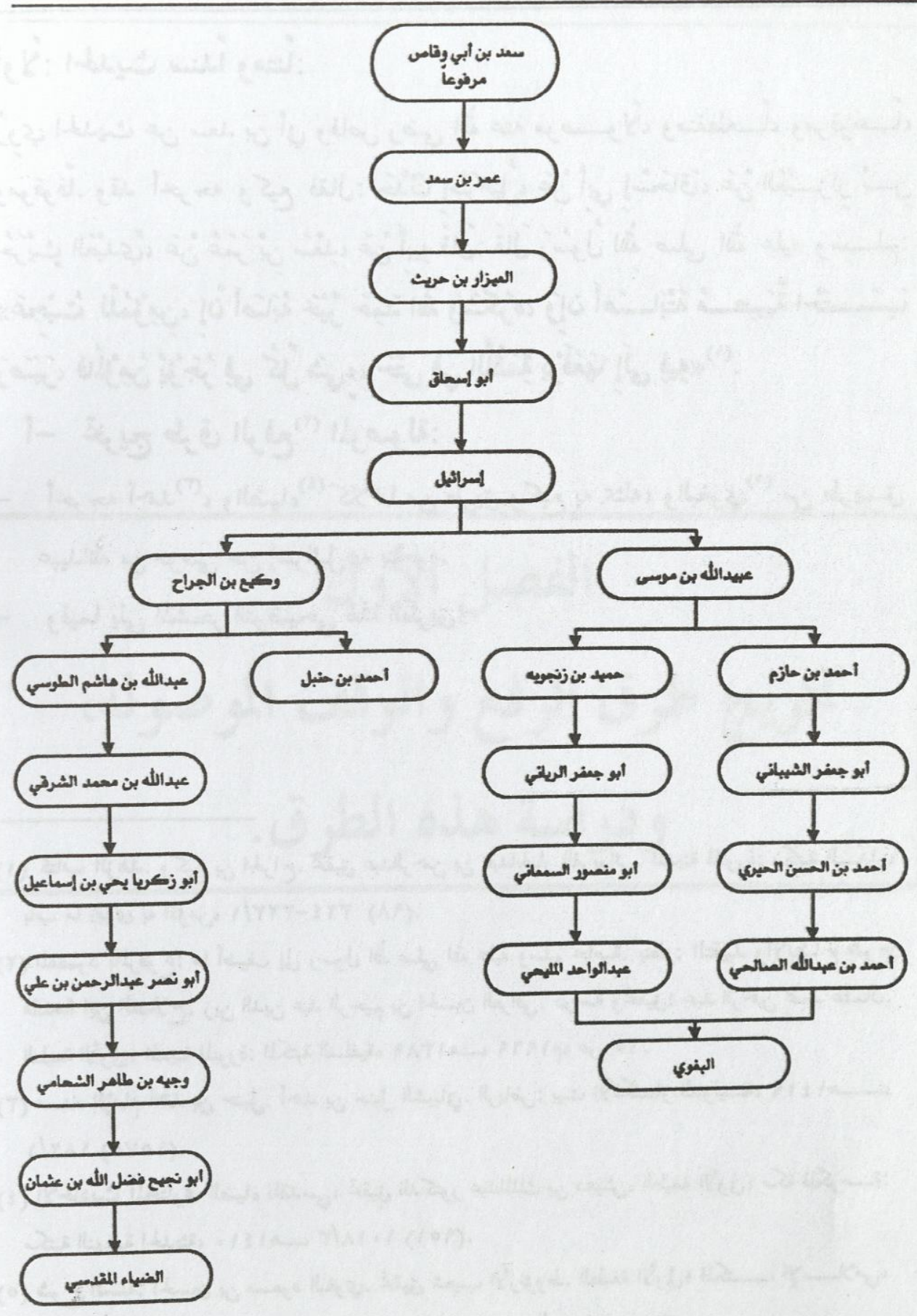

$-7 \varepsilon \cdot-$ 

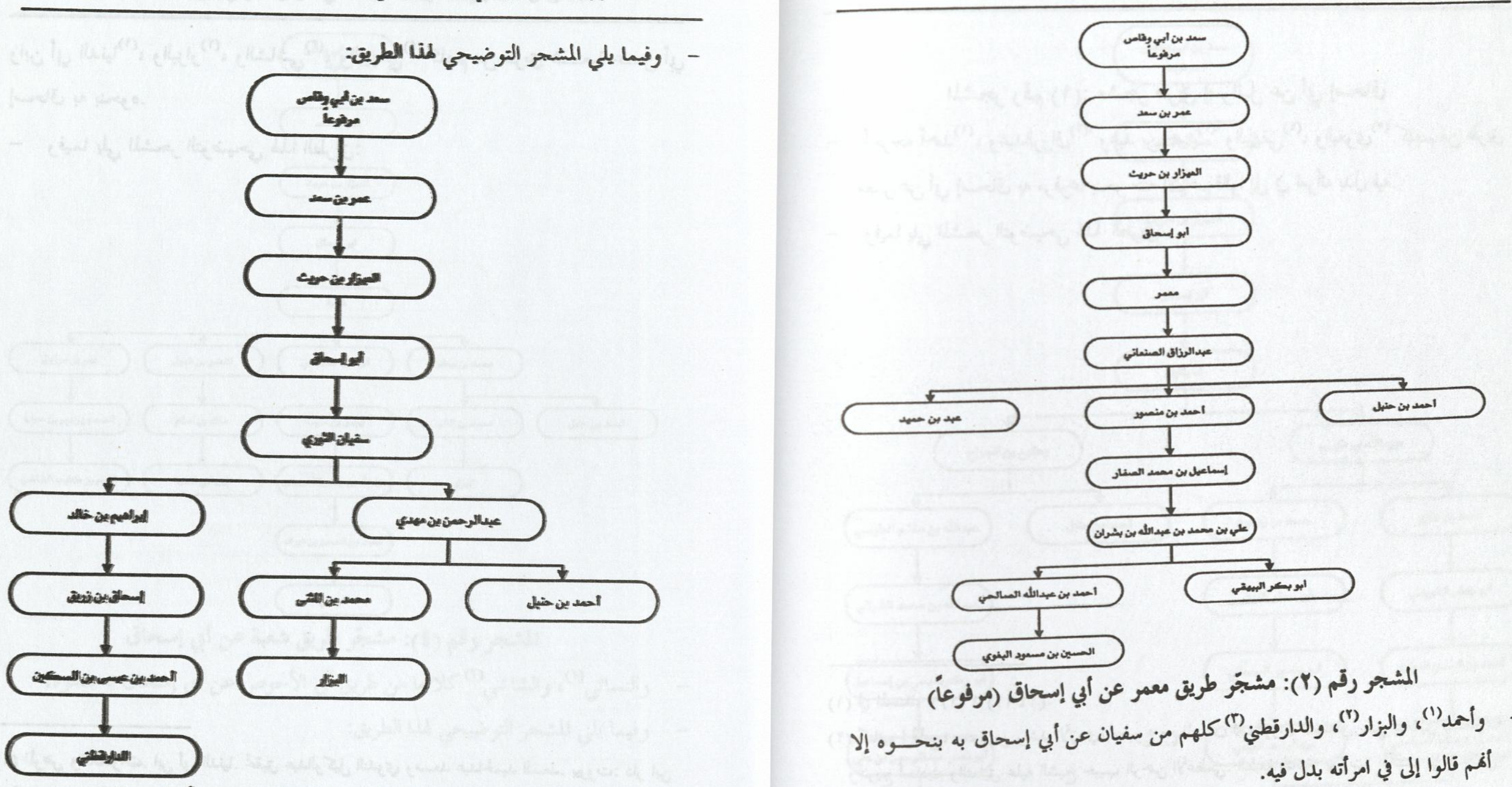

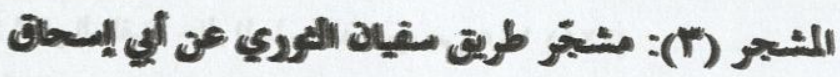

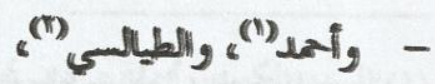

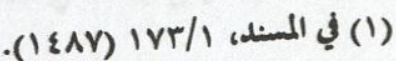

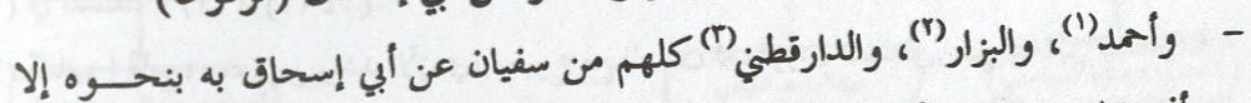
أفم قالوا إلى في امرأته بدل فيه.

(lori) $1 \mathrm{~W} / / 1 / \mathrm{ded}$

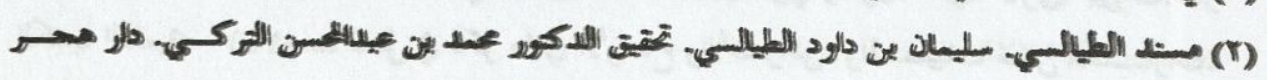

للاطباعة والتشر،

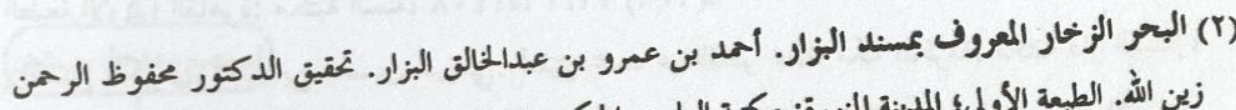

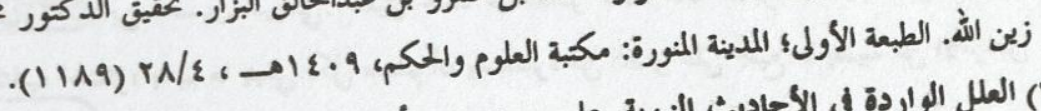

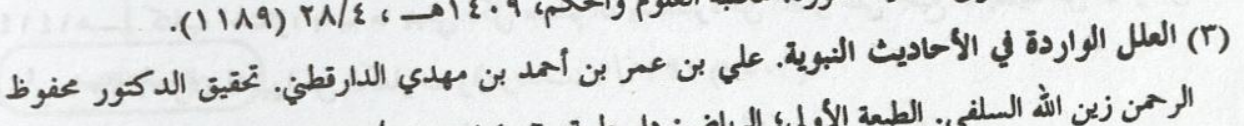

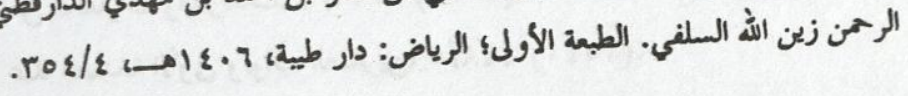




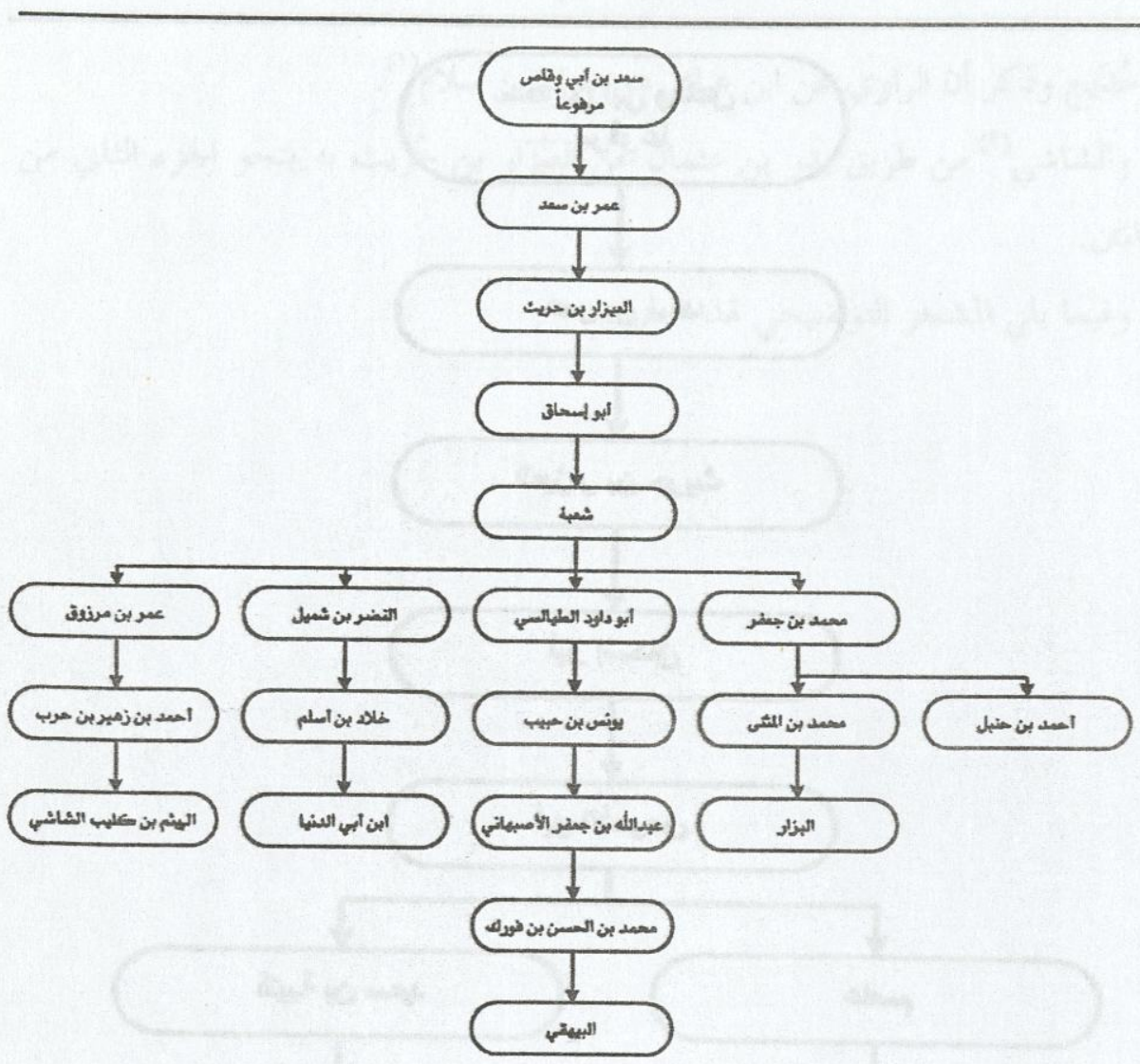

المشجر رقم (ع): مشجر طريق شعبة عن أبي إسحاق

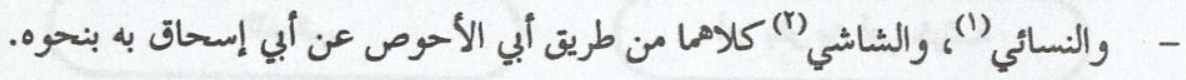

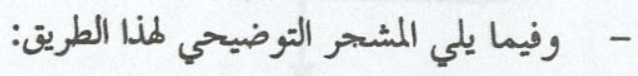

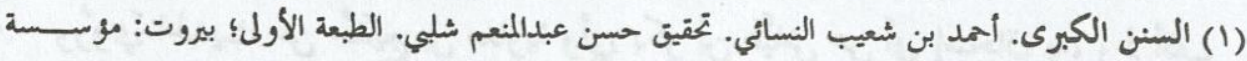

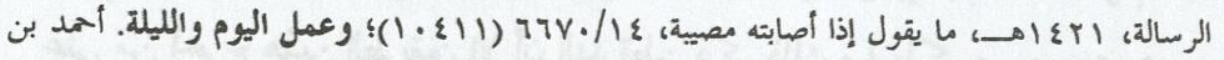

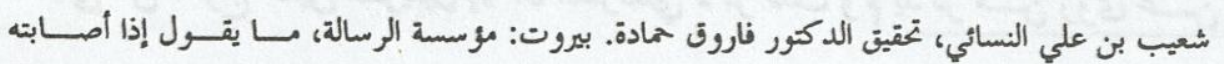

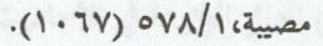
(Y) في المسنل، إ/

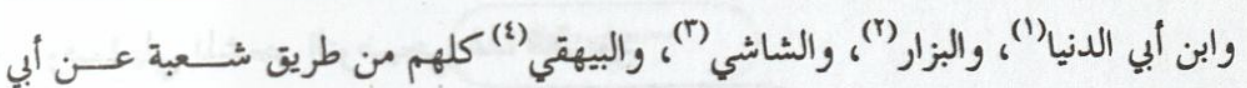
إسحاق به بنحوه. - وفيما يلي المشجر التوضيحي لهذا الطريق:

(1) المرض والكفارات. ابن أبي الدنيا. تحقيق عبدالوكيل الثدوي ومسعد عبدالحمبد السعذ. بيروت: دار ابن

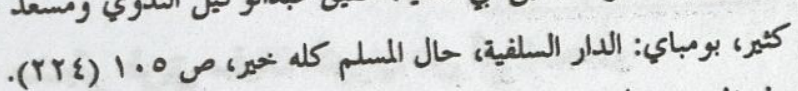
(r)

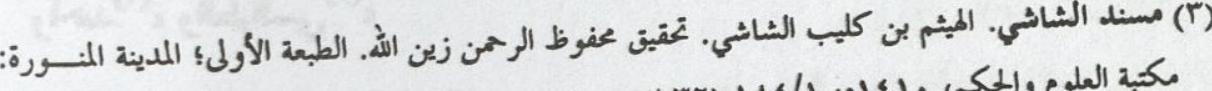

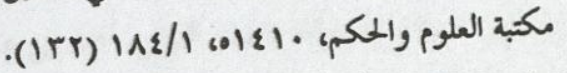

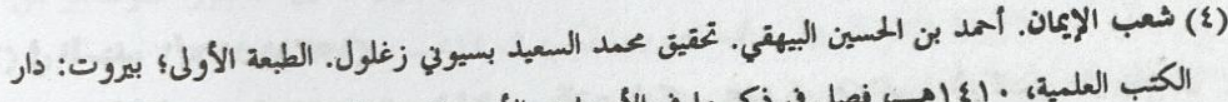

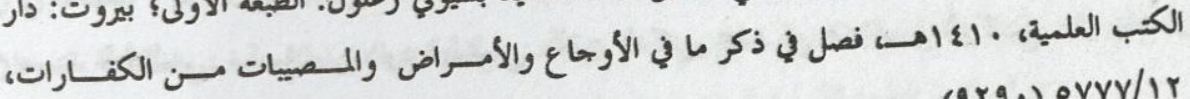
(qrq.) ० $v r v /$ ir 
حُحَديج وذكر أن الراوي عن ابن عياش هو مسلم بن سلام" (1).

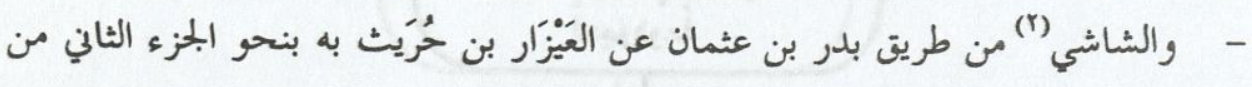
المتن.

- وفيما يلي المشجر التوضيحي لهذا الطريق:

(1) العلل الواردة في الأحاديث النبوية، ع/ror.

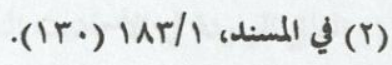

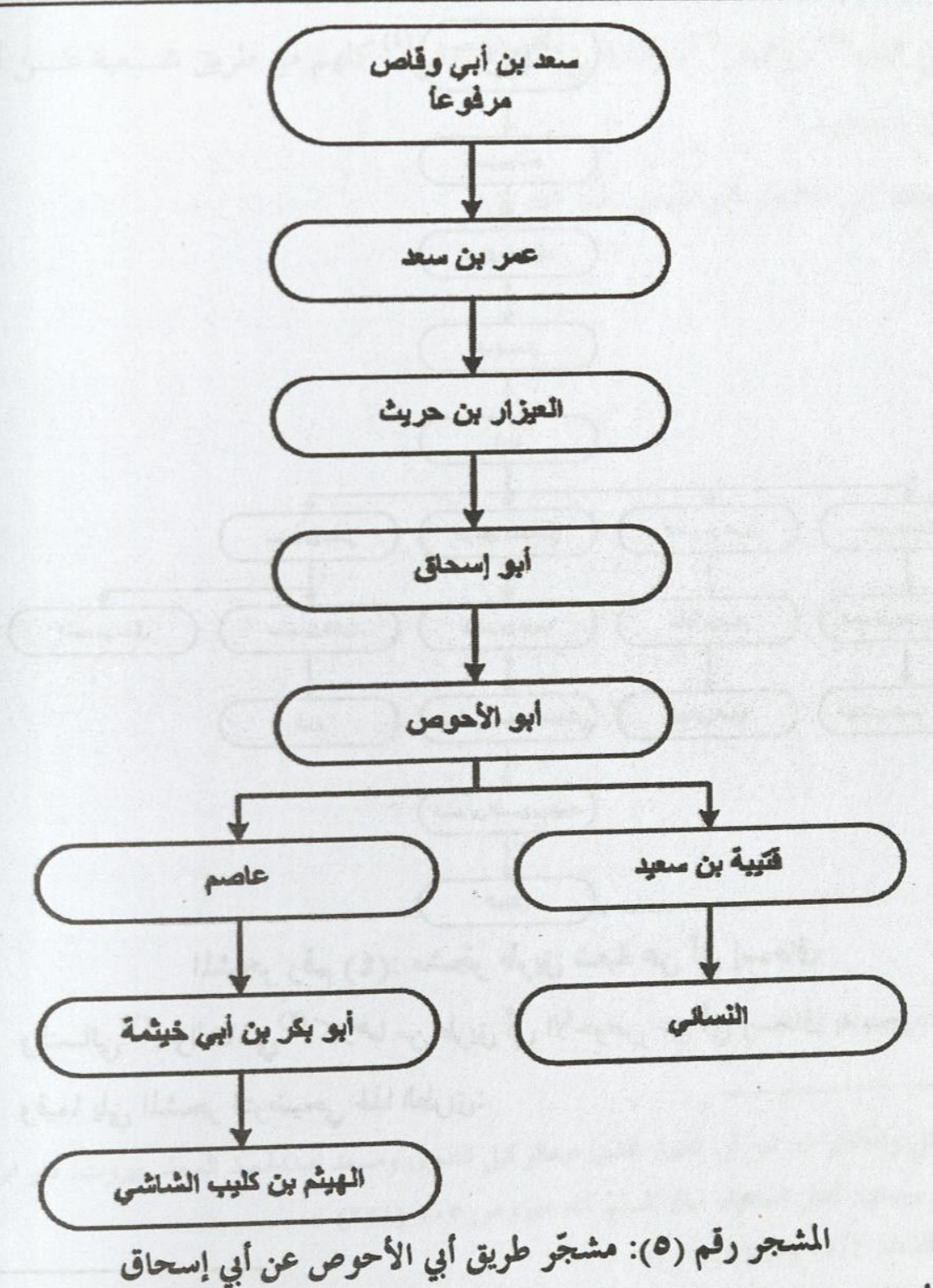

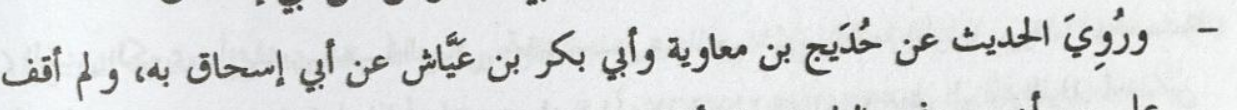

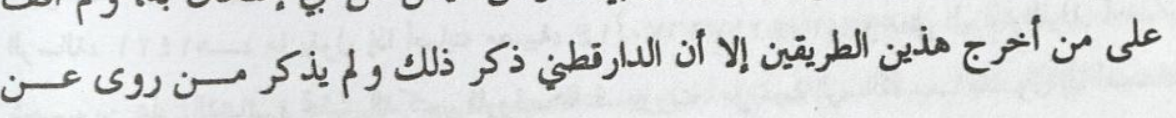




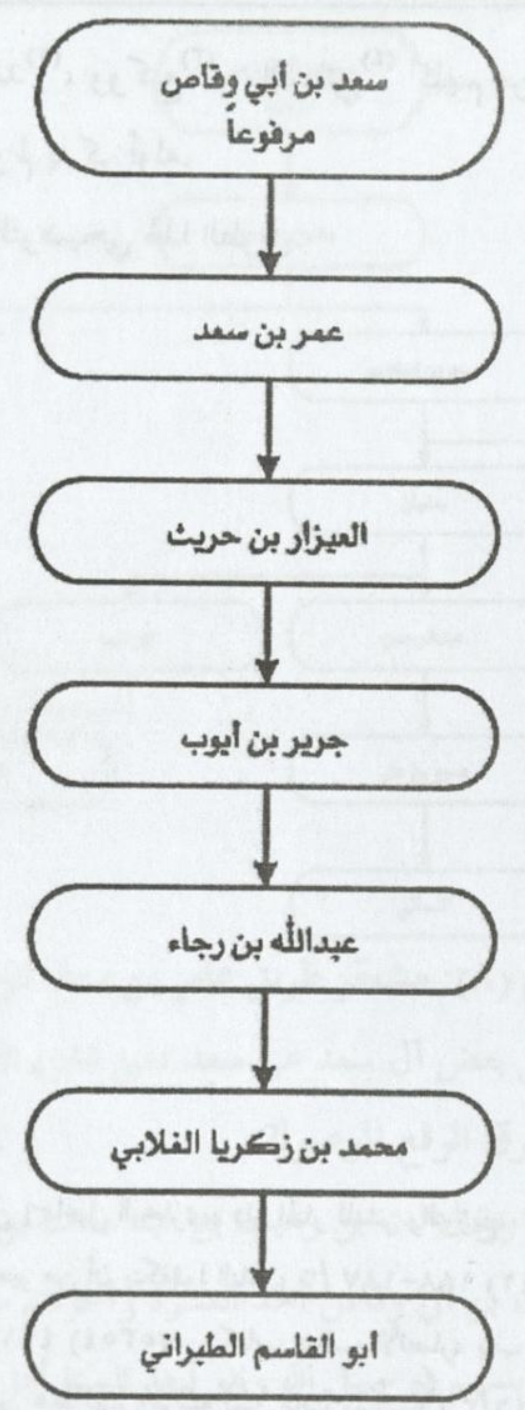

المشجر رقم (V): مشجز طريق جرير بن أيوب عن العيزار

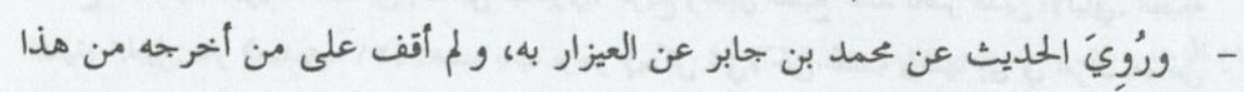

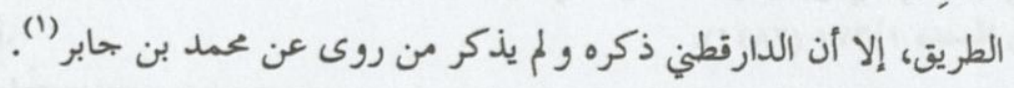

(1) العلل الواردة في الأحاديث النبوية، ع/rol.

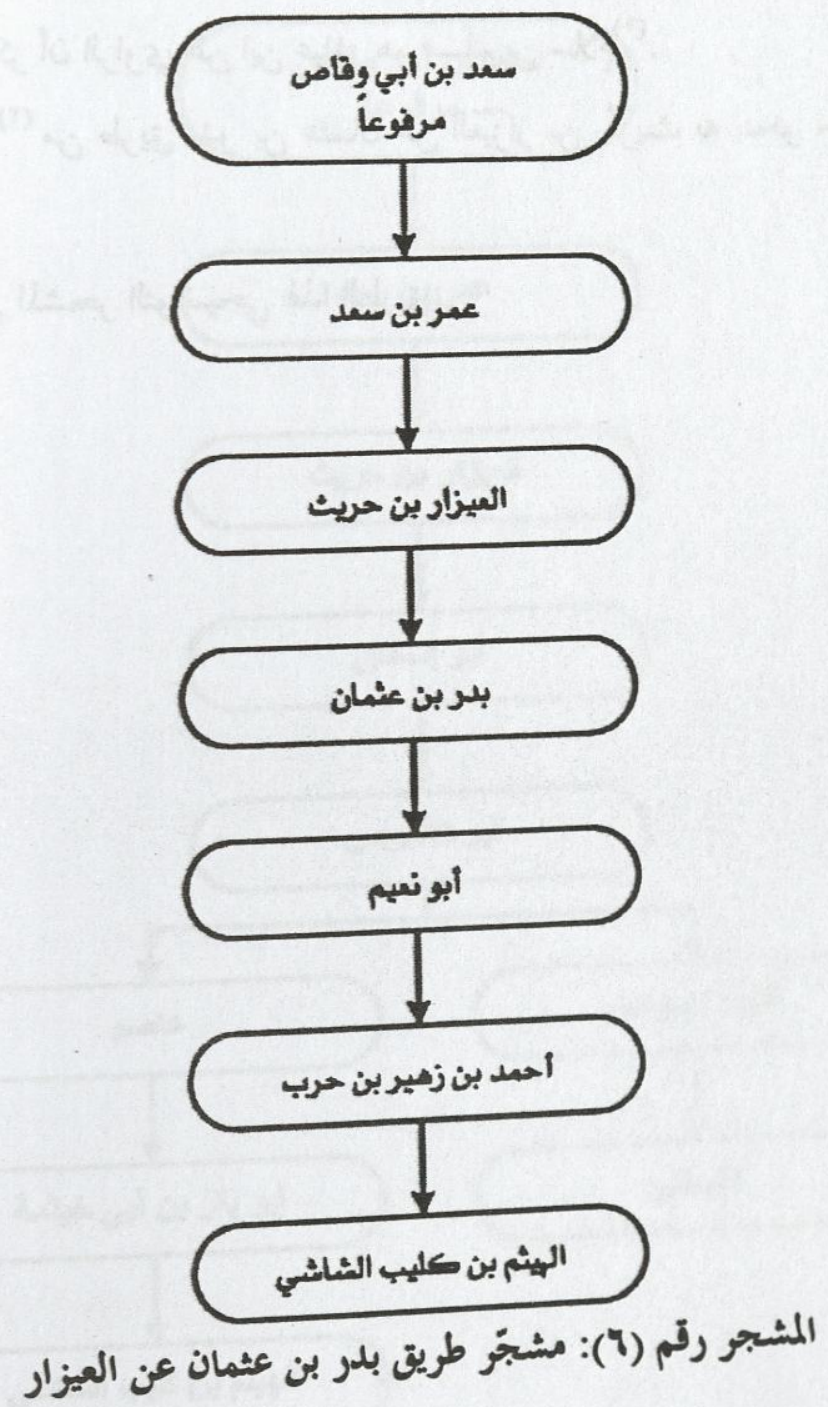

- والطبراني (1) من طريق جرير بن أيوب عن العيزار به بنحوه. - وفيما يلي المشحر التوضيحي لهذا الطريق:

(1) المعجم الأرسط. سليمان بن أمد الطبرالي. تحقيق طارق بن عوض الله بن محمد. القاهرة: دار الحــــمين،

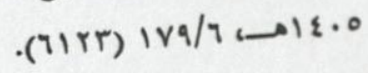




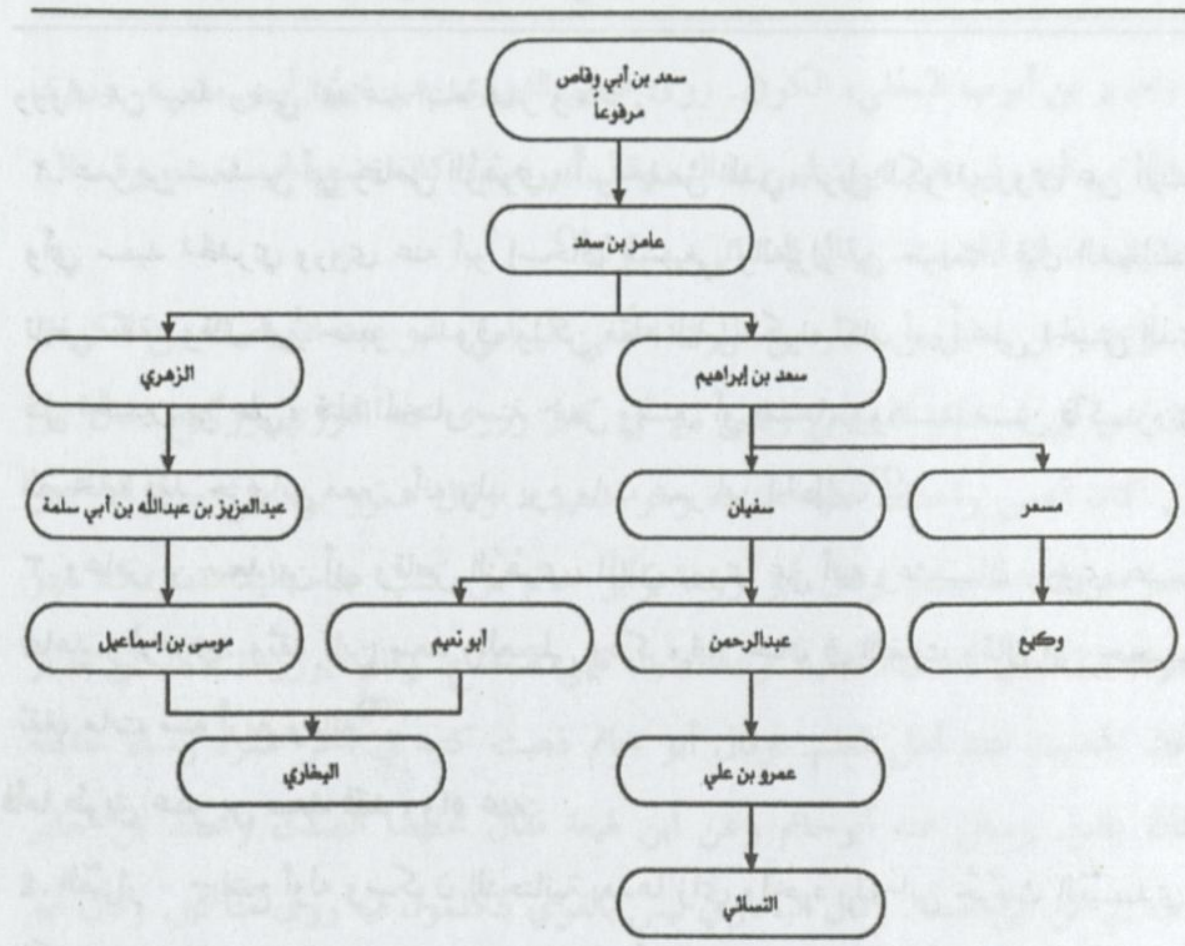

المشجو رقم (^): مشجّر طريق عامر بن سعد عن أبيه

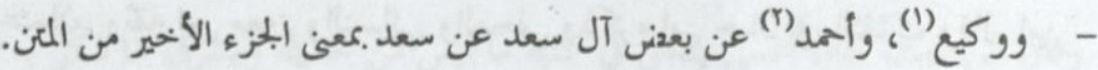
- دراسة رجال أسانيد طرق الوفع الموصولة:

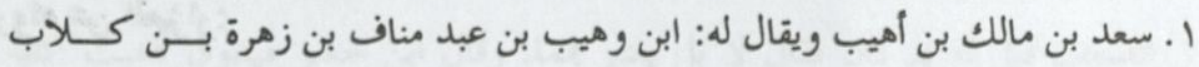

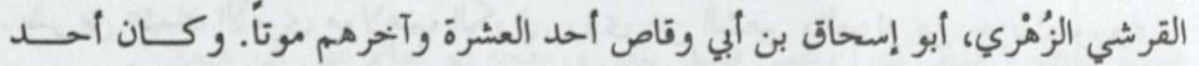
الفرسان وهو أول من رمى بسهم في سبيل الله وهو أحد الستة أهل الشورى (r)".

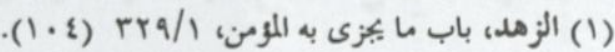

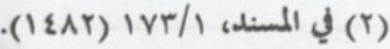

(r) الإصابة في تميز الصحابة. أحد بن على بن ححر العسقلاني. تحفيق علي عحد البهاوي. الطبعة الأولى؛

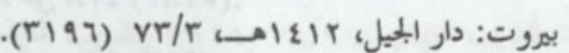

- - والبخاري(") وأحمد(1)، وركيع()، والنسائي() كلهم من طريق عامر بن سعد عن سعد بيزء من متنه ولم يذكر أوله. - - وفيما يلي المشحر التوضيحي لهذا الطريق:

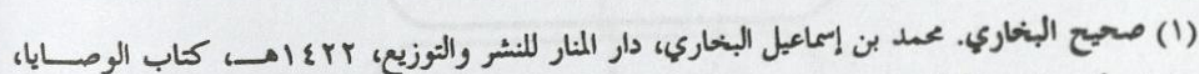

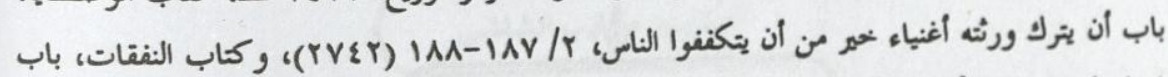

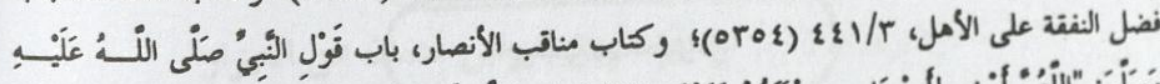

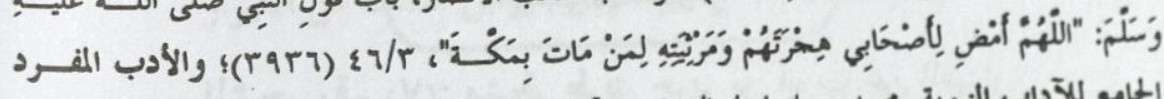

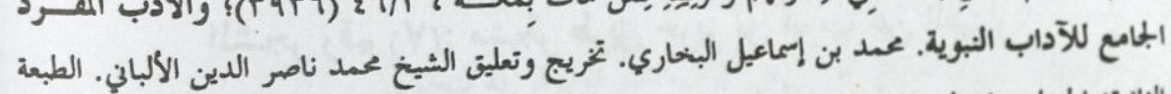

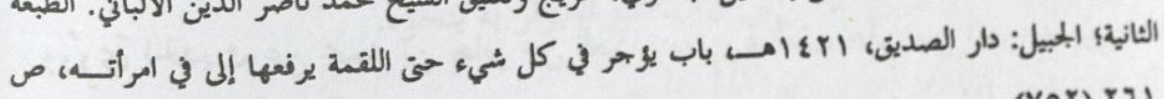

(Vor) rור

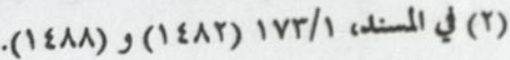

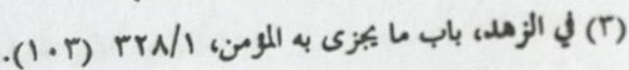

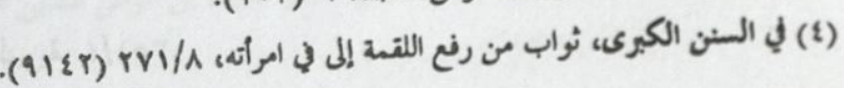


7. وجَرِير بن أيوب البَجَلي، الكوفي. روى عباس الدوري عن ييى: ليس بشيء. وروى

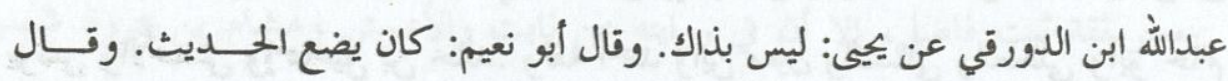

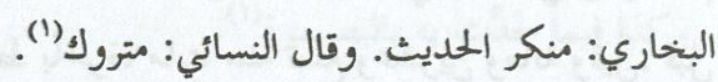

V. ومحمد بن جابر بن سيار بن طارق الحَنَفي اليمّامي، أبو عبد الله أصله من الكوفة. روى عن أبي إسحاق السبيعي وييى بن أبي كثير وروى عنه الثوري ووكيع. قال ابن بن بن بن معين كان أعمى واختلط عليه حديثه وهو ضعيف. وقال عمرو بن علي صدوق كثير الوهم متروك الحديث. وقال أبو زرعة وأبو حاتم من كتب عنه باليمامة و.مكة فهو صدوق إلا أن في أحاديثه تخاليط وأما أصوله فهي صحاح. وقال أبوزرعة محمد بن جابر ونه ساقط الحديث عند أهل العلم. وقال أبو حاتم ذهبت كتبه في آخر عمره وماء حفظه وكان يلقن. وسئل عنه أبوحاتم وعن ابن لهيعة فقال محلهما الصدق ومحمد بن جابر أحب إلي من ابن الميعة. وقال البخاري ليس بالقوي يتكلمون فيه روى مناكير. وقال أبو داود ليس بشيء. وضعفه النسائي ويعقوب بن سفيان والعحلي وقال الذهلي لا بأس به. وقال ابن حبان كان أعمى يلحق في كتبه ما ليس من حديثه ويسرق ما ذكر به فيحدث به. وقال أحمد بن حنبل لا يحدث عنه إلا شر منه. وقال الدارقطني هو وأخوه يتقاربان في الضعف قيل له يتركان فقال لا بل يعتبر هما. وقال ابن ححر صدوق ذهبت كتبه

فساء حفظه وخلط كثيراً وعمي فصار يلقن ورجحه أبو حاتم على ابن لهيعة(r). ^. وأبو إسحاق، عمرو بن عبد الله بن عبيد ويقال: علي ويقال ابن أبي شعيرة الهَمْداني، السببيعي -بفتح المهملة وكسر الموحدة- الكوفي. ولد لسنتين بقيتا من حلافة عينة

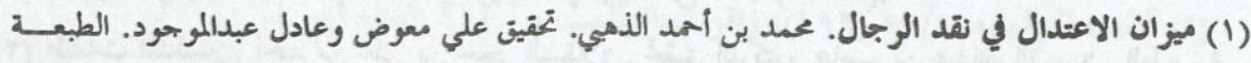

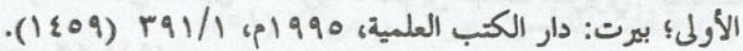

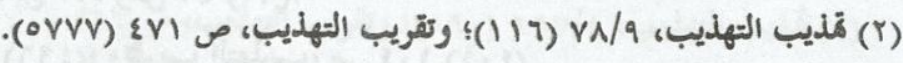

ورواه عن سعد رضي الله عنه ابناه عمر وعامر. r.عمر بن سعد بن أبي وقاص الزُهرِي، أبو حفص المدني، نزيل الكوفة، روى عن عن أبيـهـ

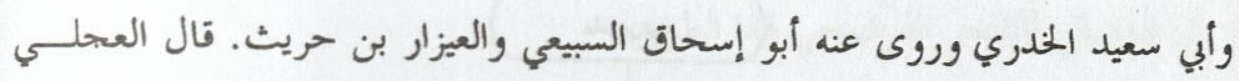
تابعي ثقة، وقال ابن حجر صدوق ولكن مقته الناس لكونه كان أميراً على الجيش الذي

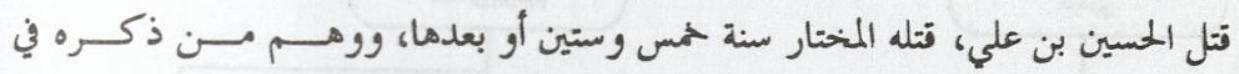

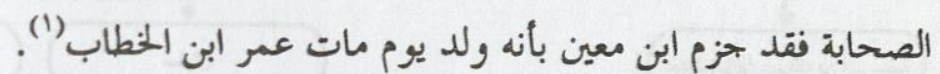

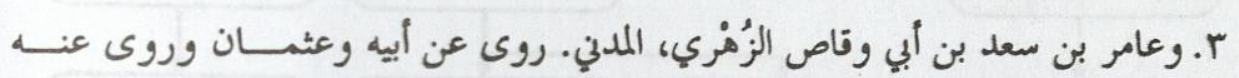

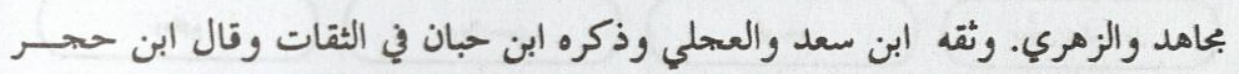

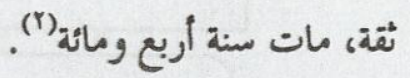

فأما طريق عمر بن معد فقد رواه عنه:

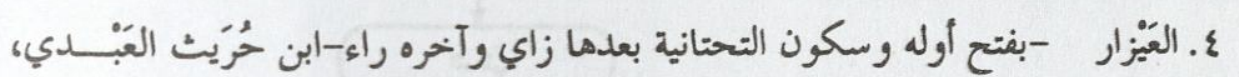

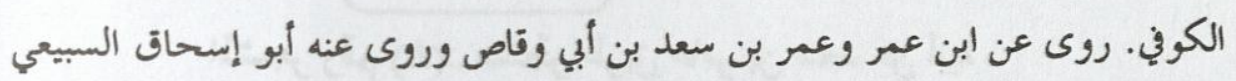

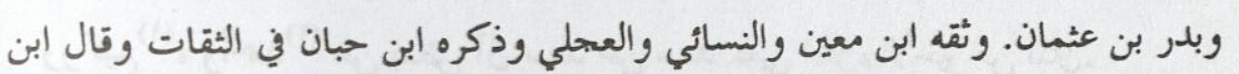

حجر ثقة، مات بعد سنة عشر ومائة (r) ورواه عن العيزار: - م ه. بدر بن عثمان الأموِي مولاهم، الكوين. روى عن الشعبي والعيزار بن حريث وروى وعى

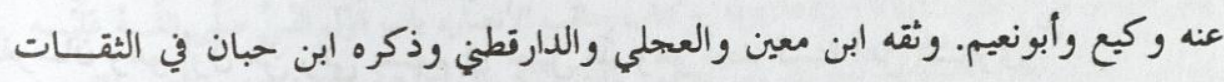
وقال النسائي ليس به بأس وقال ابن حجر ثقة (ع).

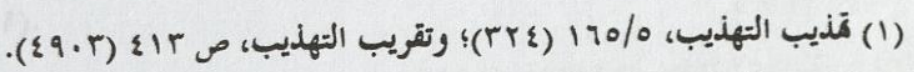

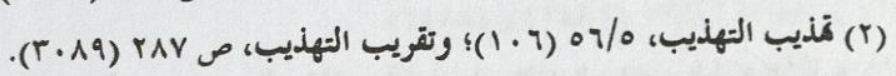

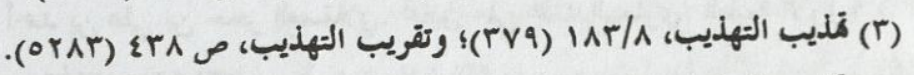

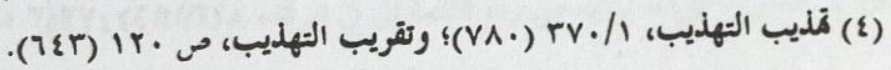
-ror- 
ابن حبان في الثقات وقال كان فقيهاً حافظاً متقناً ورعاً. وأثنى عليه الشافعي. وقال ابن حجر ثقة ثبت فاضل، إلا أن في روايته عن ثابت والأعمش وهشام بن عروة شئـئان

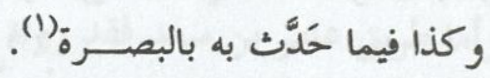

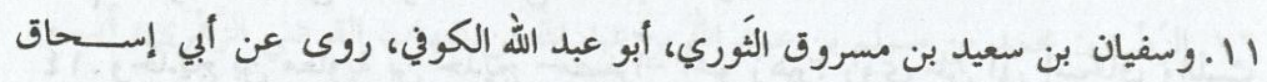

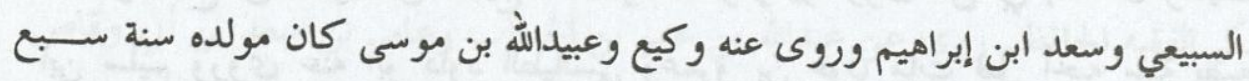

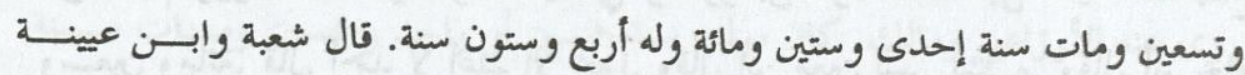

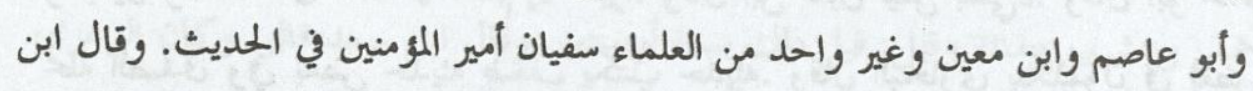
معين مرسلاته شبه الريح وكذا قال أبو داود قال ولو كان عنده شيء لصاح به. ووثقه ابن سعد، وقال النسائي هو أجل من أن يقال فيه ثقة. وقال ابن حسر ثقة حافظ فقيــه

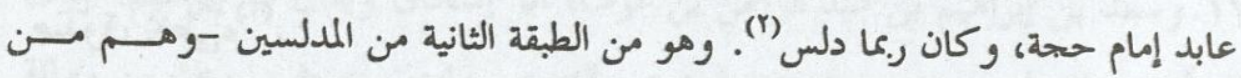

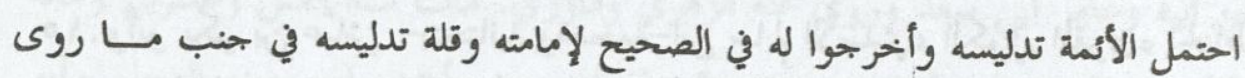
كالثوري أو كان لا يدلس، إلا عن ثقة كابن عيية (r).

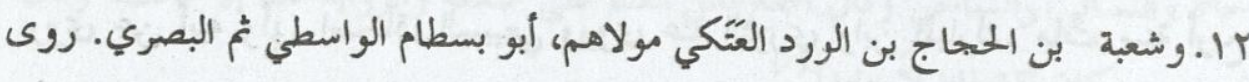

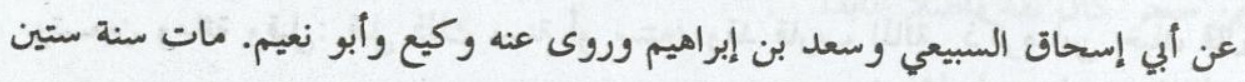

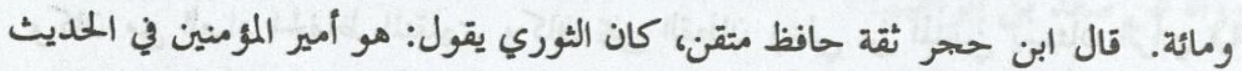

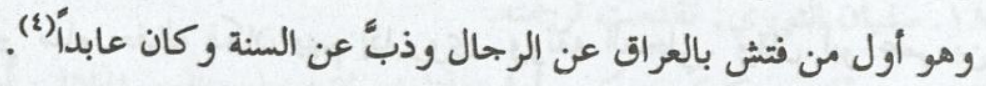

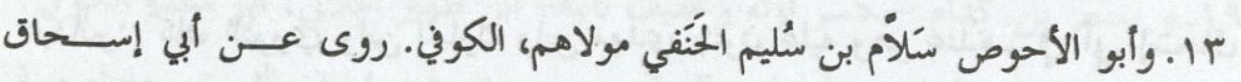

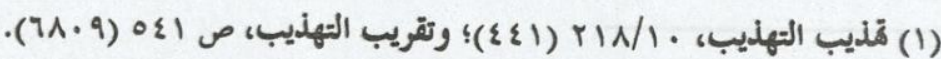

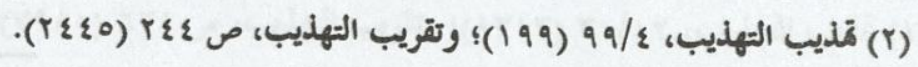

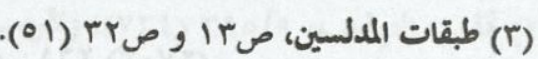

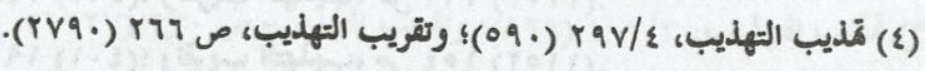
$-900-$
عثمان. روى عن مصعب وعامر ابني سعد بن أبي وقاص وروى عنه ابن ابنه إسرائيل بن

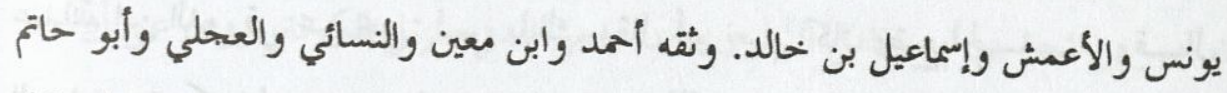

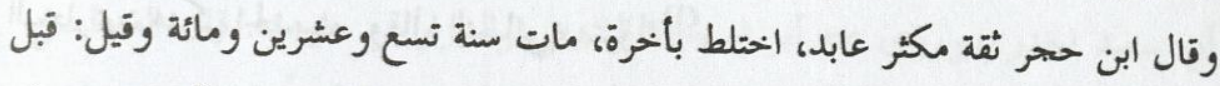

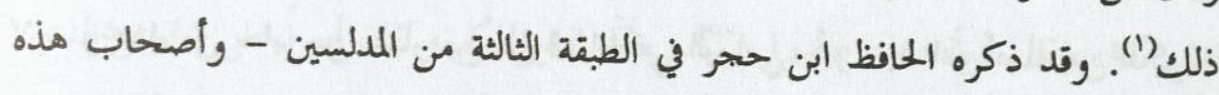

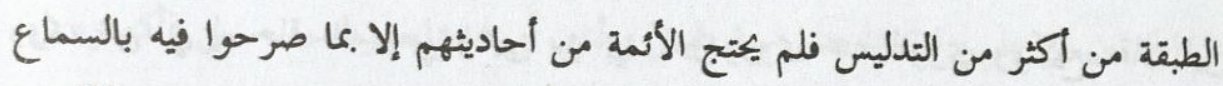

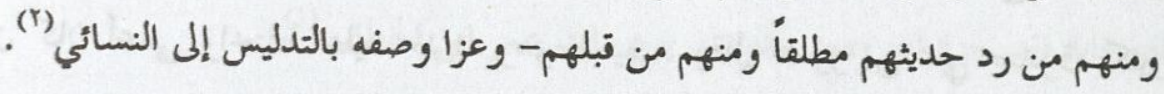
ورواه عن أبي إسحاق: 9. إسرائيل بن يونس بن أبي إسحاق السببعي الهُمْداني، أبو يوسف الكوفي. روى عن

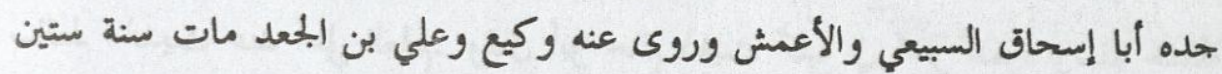

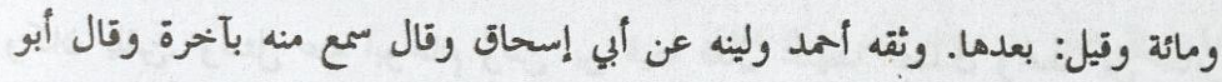
حاتم ثقة صدوق ومن أتقن أصحاب أبي إسحاق ووثقه العحلي وقال يعقوب بن شيبة صالح الحديث وفي حديثه لين وقال النسائي ليس به بأس وضعفه ابن المديني وقال ابن إبن

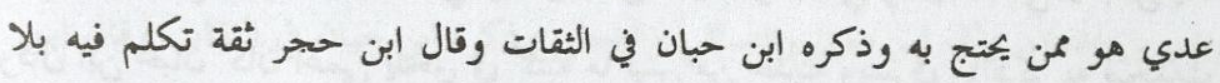
حجة (r) • ا. ومَعْمر بن راشد الأزْدِي مولاهم، أبو عروة البصري، نزيل اليمن. روى عن قتادة

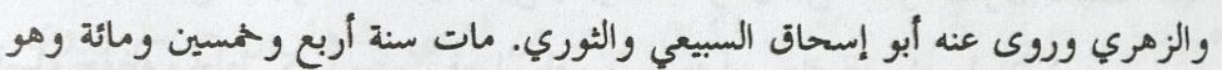

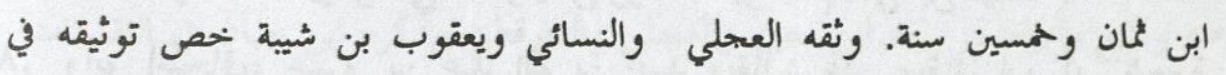

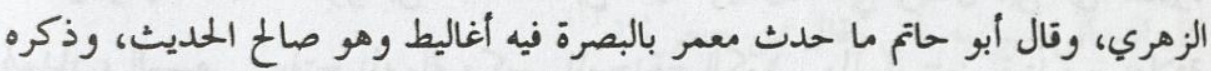

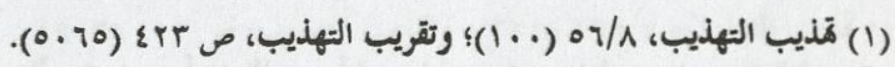

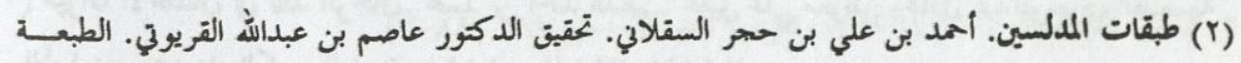

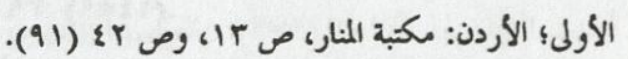

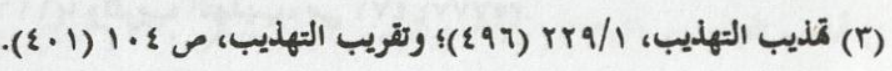
$-908-$ 
يكن بالحافظ وقد حدث عنه أهل العلم واحتملوا حديثه. وقال ابن حجر ثقة عابد إلا أنه لما كبر ساء حفظه وكتابه صحيح (1) وأما طريق عامر بن سعد فقد رواه عنه:

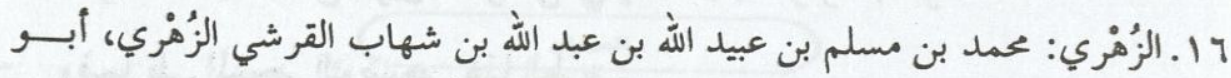

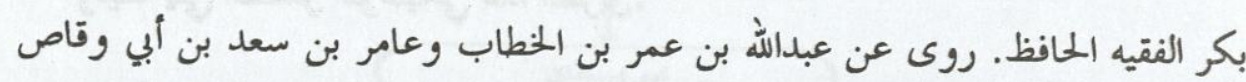

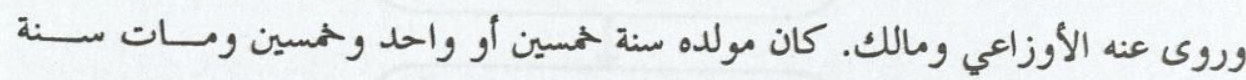
حمس وعشرين ومائة وقيل: قبل ذلك بسنة أوسنتين. وقال ابن سعد قالوا وكان الزهري

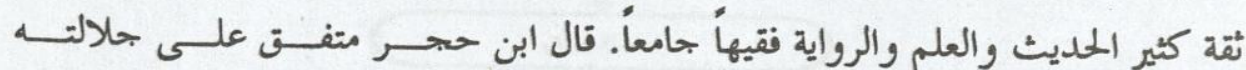
وإتقانه (r) Vا ـ وسعد بن إبراهيم بن عبد الرحمن بن عوف، أبو إسحاق ويقال أبو إبراهيم. روى

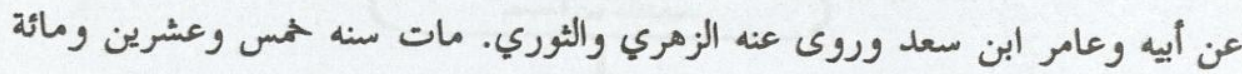

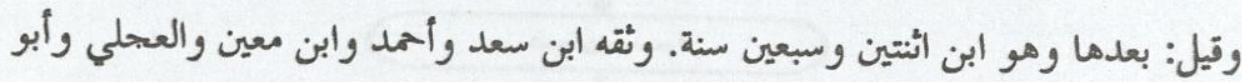

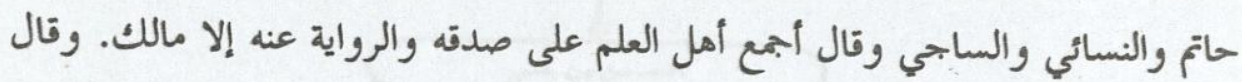

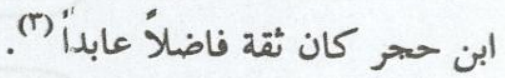
ورواه عن سعد بن إبراهيم: 11 ا. سفيان الثوري: تقدمت ترجمته. 19 ــ و مسنعر بن كِدَام -بكسر أوله وتخفيف ثانيه- ابن ظهير الهِلالي، أبو سلمة الكوفي. روى عن سعد ابن إبراهيم وأبي إسحاق السبيعي وروى عنه شعبة والثوري. مات سنة ثلاث أو حمس وحمسين ومائة. وثقه ابن المديني وأحمد والعجلي وابن معين وابن عمار

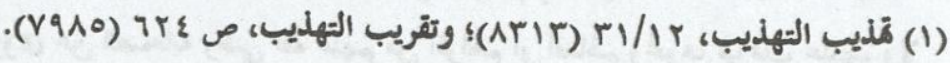

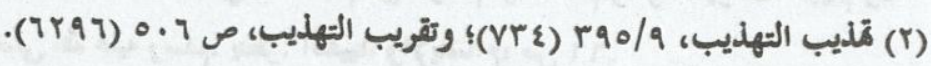

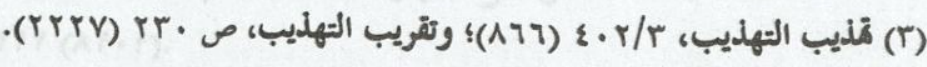

السبيعي والأعمش وروى عنه وكيع وابن مهدي. مات سنة تسع وسبعين ومائة. وئقـهـ

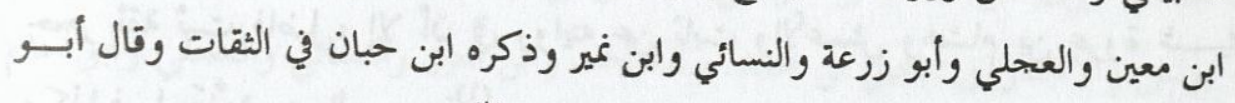

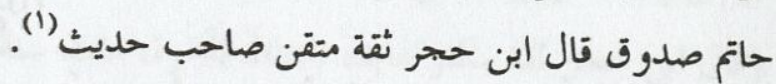
عا. وحُدَيج بن معاوية بن حُديج -مصغراً- أخو زهير. روى عن أبي إسحاق والليث

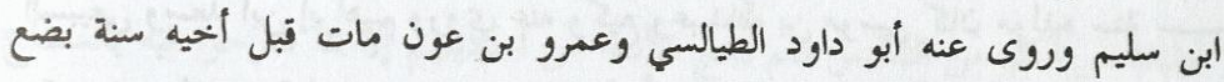

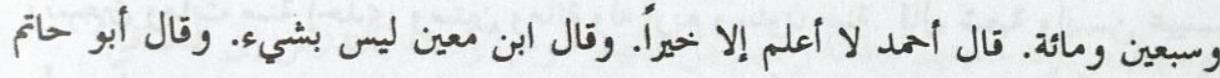
عحله الصدق وفي بعض حديثه ضعف يكتب حديثه. وقال البخاري يتكلمون في بعض ومانه حديثه وضعفه ابن سعد والنسائي. وقال الدارقطين غلب عليه الوهم. وقال ابن حبان إندان

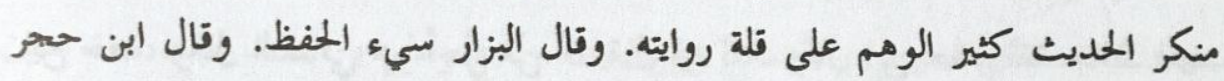
صدوق يخطى (r) 1 1 وأبو بكر بن عيّاش -بتحتانية ومعحمة-ابن سالم الأسَدي، الكوفي المقرىء الحناط -مهملة ونون- مشهور بكنيته والأصح أفا اسمه، واختلف في اسمه على عشرة أقوال.

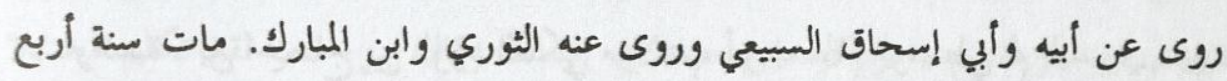
وتسعين ومائة وقيل: قبل ذلك بسنة أو سنتين وقد قارب المائة. ذكره ابن حبان قال وكان من العباد الحفاظ المتقنين. وكان ييى القطان وعلي بن المديني يسيئان الرأي فيه وذلك أنه لما كبر ساء حفظه فكان يهم إذا روى. ووثقه العجلي. وقال أبو عمر بن عبدالبر: كان الثوري وابن المبارك وابن مهدي يثنون عليه وهو عندهم في أبي إسحاق مثل شريك وأبي الأحوص إلا أنه يهم في حديثه وفي حفظه شيء. وقال الساجي: صدوق يهم. وقال أبو نعيم: لم يكن في شيوخنا أحد أكثر غلطاً منه. وقال البزار: لم

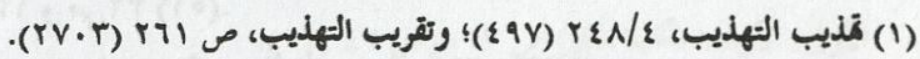

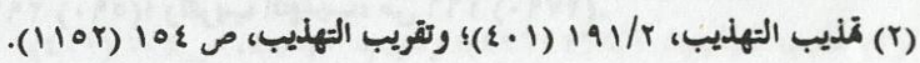
$-909-$ 


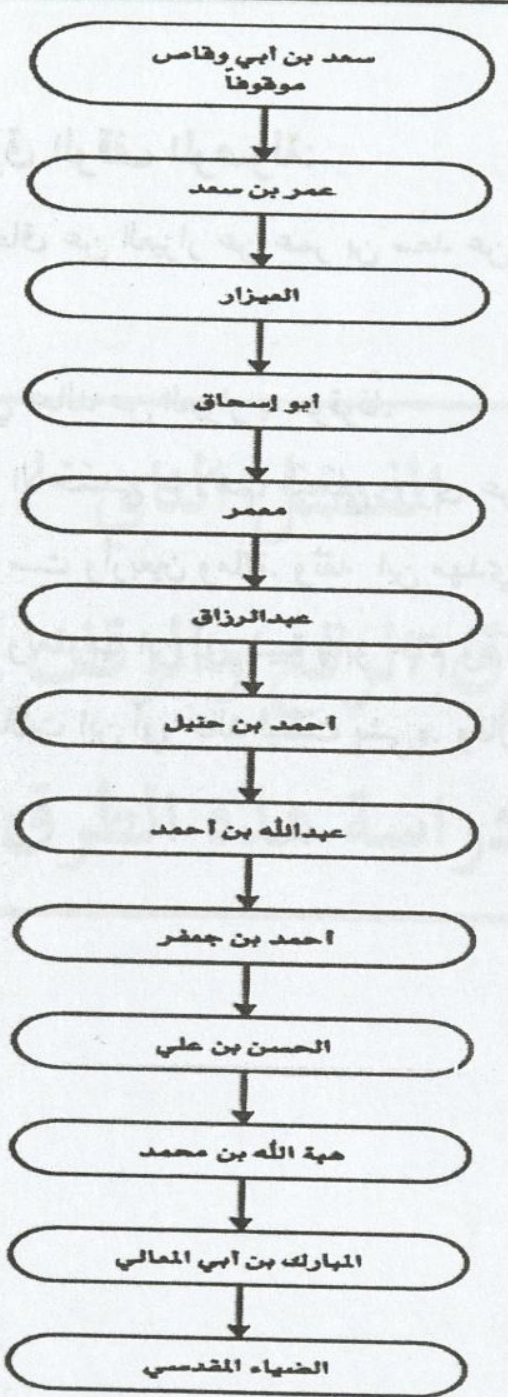

المشجر رقم (9): مشجر طريق معمر عن أبي إسحاق (موقوفا)

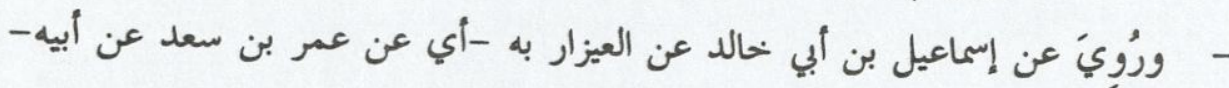

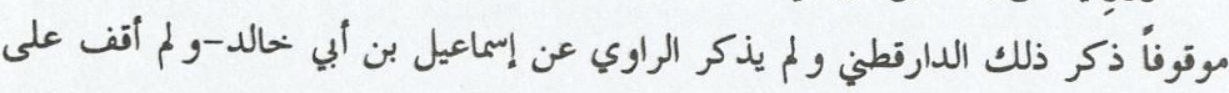

وأبو زرعة وأبو حاتم. وقال ابن حجر ثقة ثبت فاضل (')

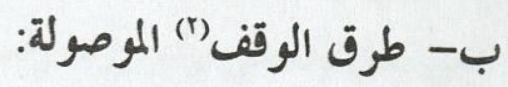

- أخرجه الضياء"(r) من طريق معمر عن أبي إسحاق به موقوفاً بنحوه. - - وفيما يلي المشجر التوضيحي لهذا الطريق:

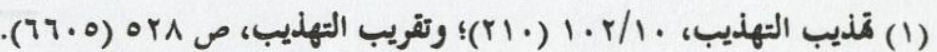

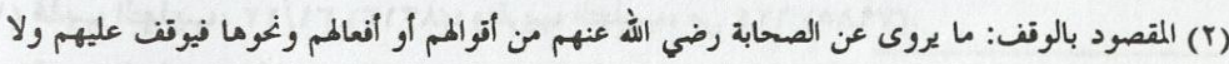

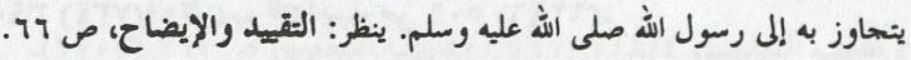

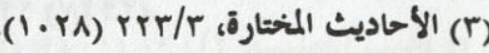




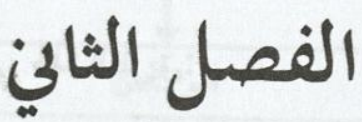

\section{تخريج طرق الرفع والوقف المنقطعة، ودراسة هذه الطرق.}




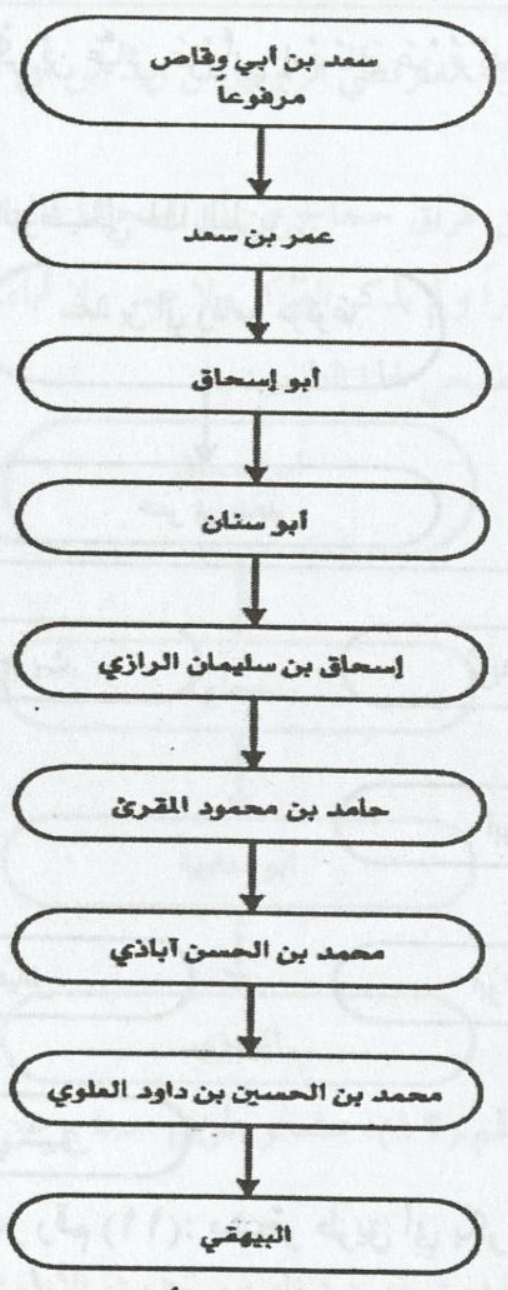

المشجر رقم (• (1): مشجر طريق أبي سنان عن أبي إسحاق

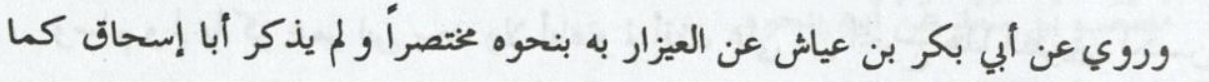

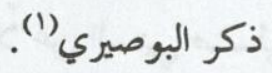

(1) إتحاف المحيرة المهرة بزوائد المسانيد العشرة. البوصيري. تحقيق أبي عبد الرحمن عادل بــن سـسل وأبي

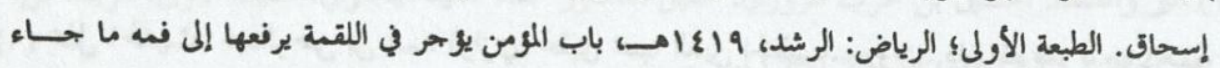

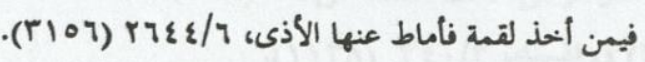
- -

\section{أ- أ - طرق الرفع المنقطعة (1):}

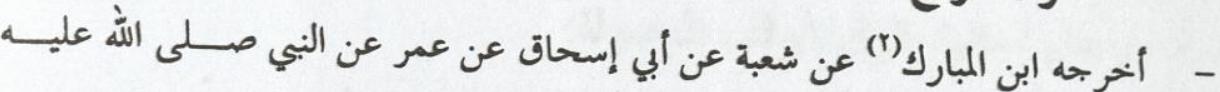
وسلم و لم يذكر سعداً، فهو مرسل.

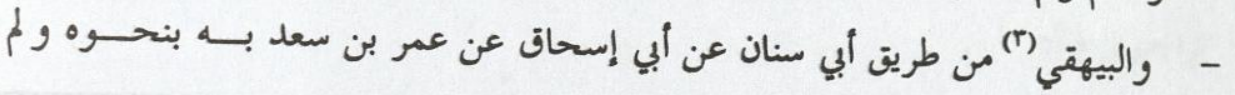
يذكر العيزار. - وفيما يلي المشحر التوضيحي لهذا الطريق:

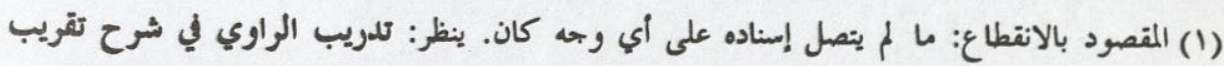

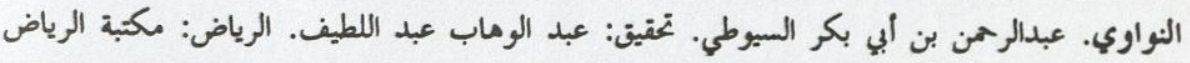

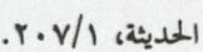
(r) كتاب الزمد والرقاتق. عبدالة بن المبارك المروزي. تحقيق الشيخ حيب الرحمن الأعظمي. بــيروت: دار

الكتب العلمية، ص و Y (110). (r) (r) شعب الإيمان، 
رواية سعد بن أبي وقاص رضي الله عنه لصديث: عجبت للمؤمن ...

الله عليه وسلم و ولم يذكر الدارقطني الراوي عن زيد ابن أبي أنيسة (1).

- - مأخرجه المروزي(r) من طريق حجاج عن أبي إسحاق قال. قال رسول الله صلى الله

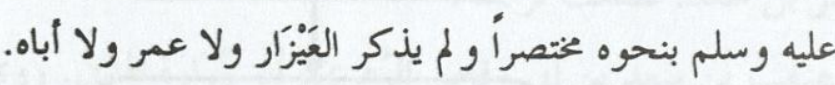

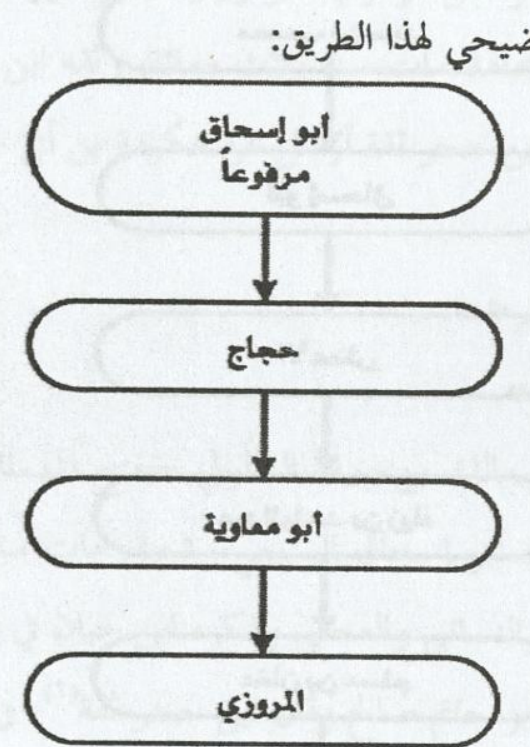

المشجر رقم (r) (1): مشجر طريق حجاج عن أبي إسحاق

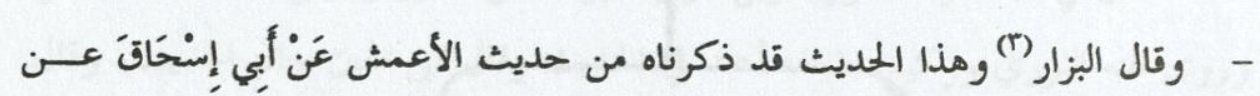

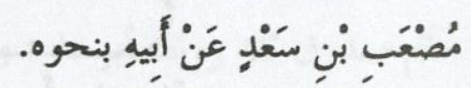

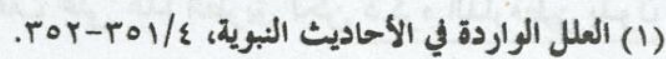

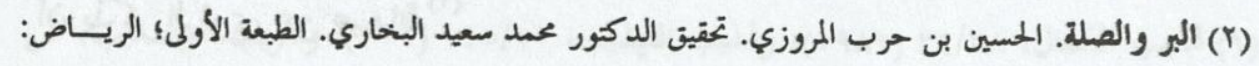

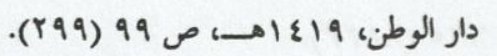

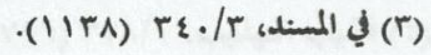

رواية سعد بن أبي وقاص رضي الله عنه لحديث: عجبت للمؤمن ...

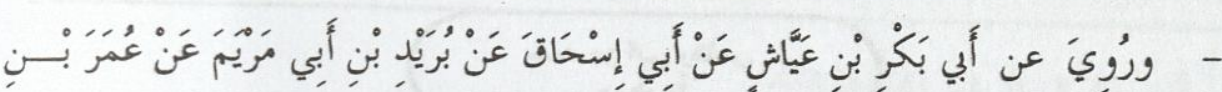

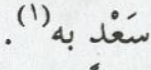

- وفيما يلي المشجر التوضيحي لهذا الطريق:

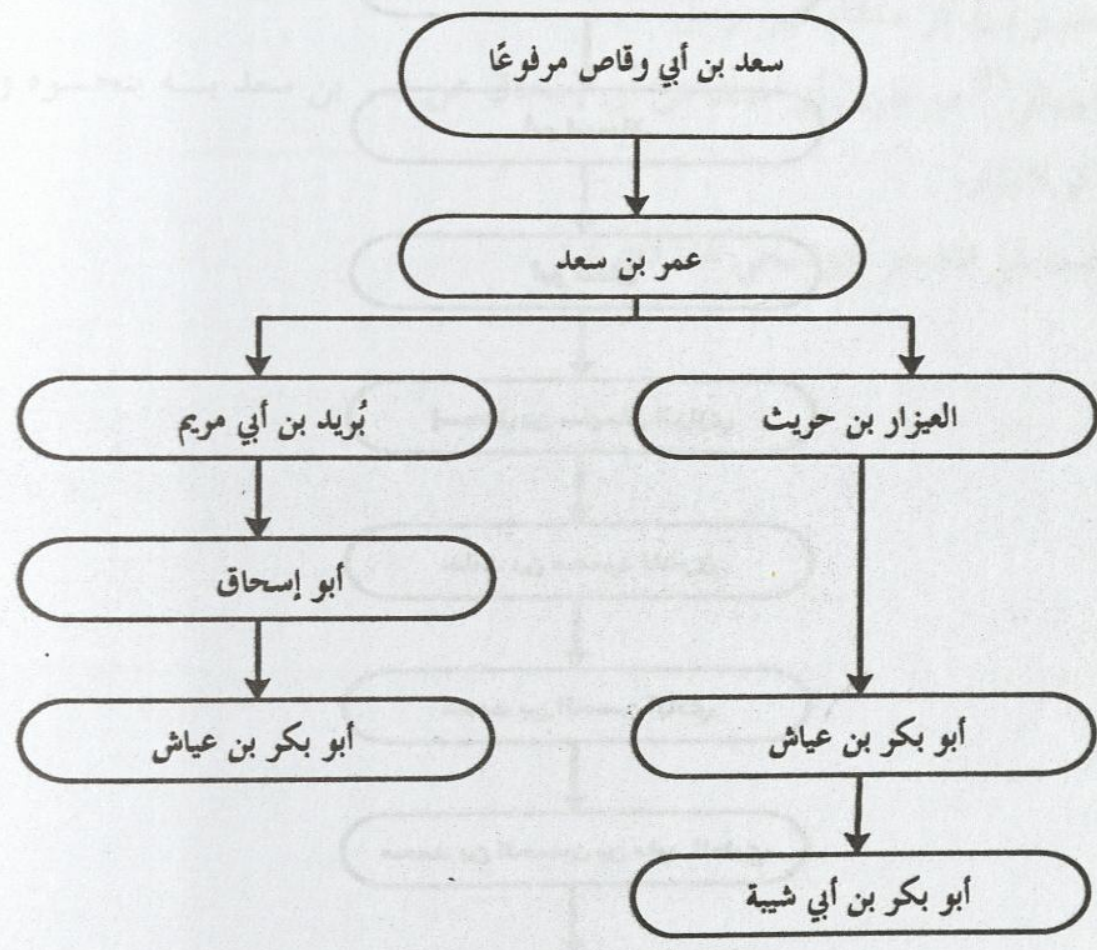

المشجر رقم (11): مشجّر طريق أبي بكر بن عياش

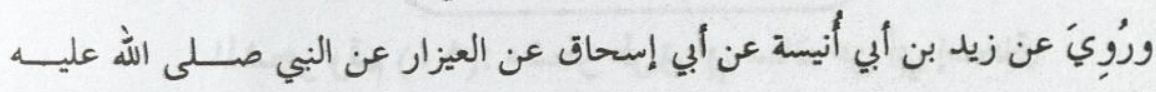

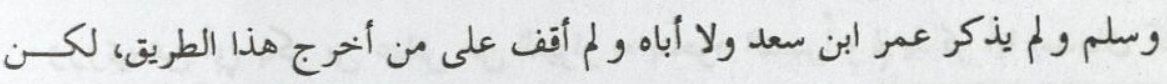

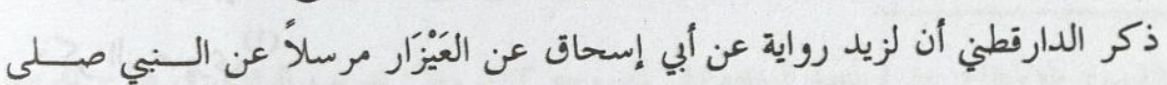

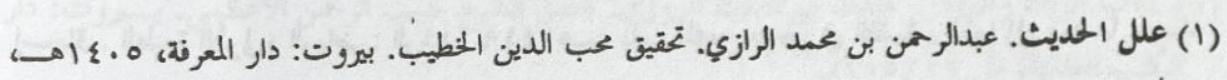
. r. (T) 
- رجال أسانيد طرق الرفع المنقطعة: رواه عن سعد رضي الله عنه: ا ـ عمر بن سعد: تقدمت ترجمته.

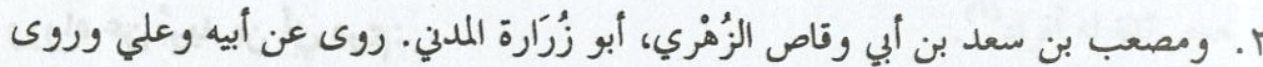

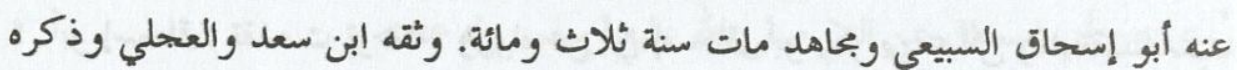

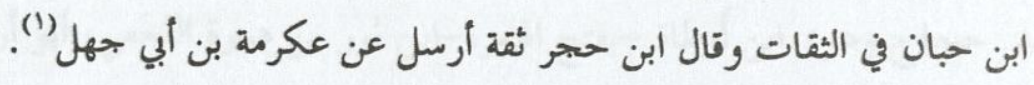

ورواه عن عمر بن سعد: - الم r. أبو إسحاق: تقدمت ترجمته. ع. ع. والعَيَْار: تقدمت ترجمته.

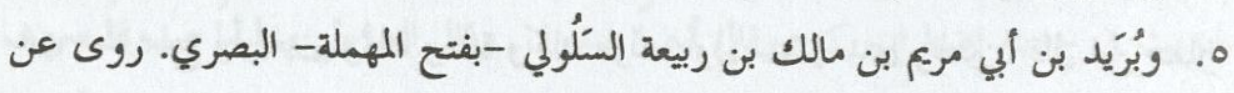
أنس وابن عباس وروى عنه أبو إسحاق السبيعي وشعبة. مات سنة أربع وأربعين ومائة. وثقه ابن معين وأبو زرعة والنسائي والعجلي وذكره ابن حبان في الثقات وقال الدارقطني

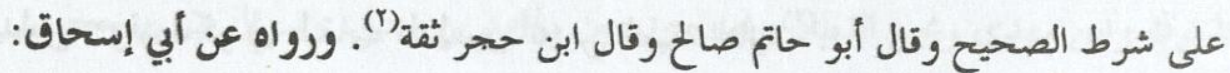

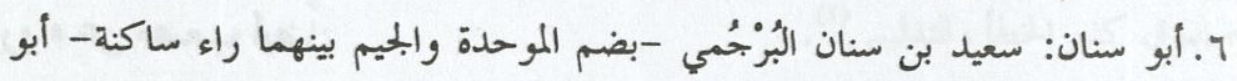

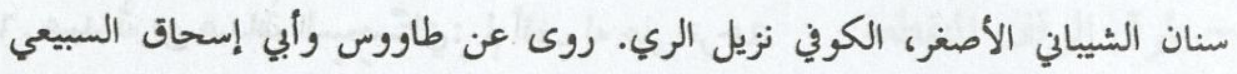

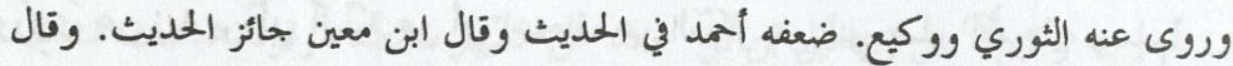
أبو حاتم صدوق ثقة ووثقه أبو داود ويعقوب ابن سفيان والدارتطني وذكره ابن حبان في

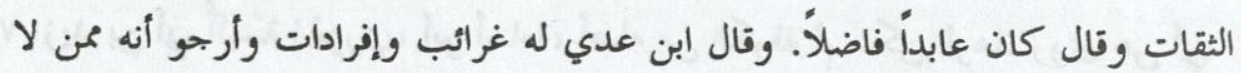

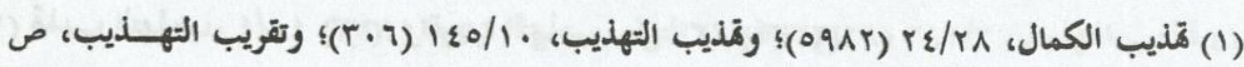

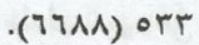

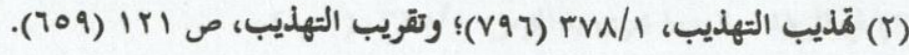
- ราท

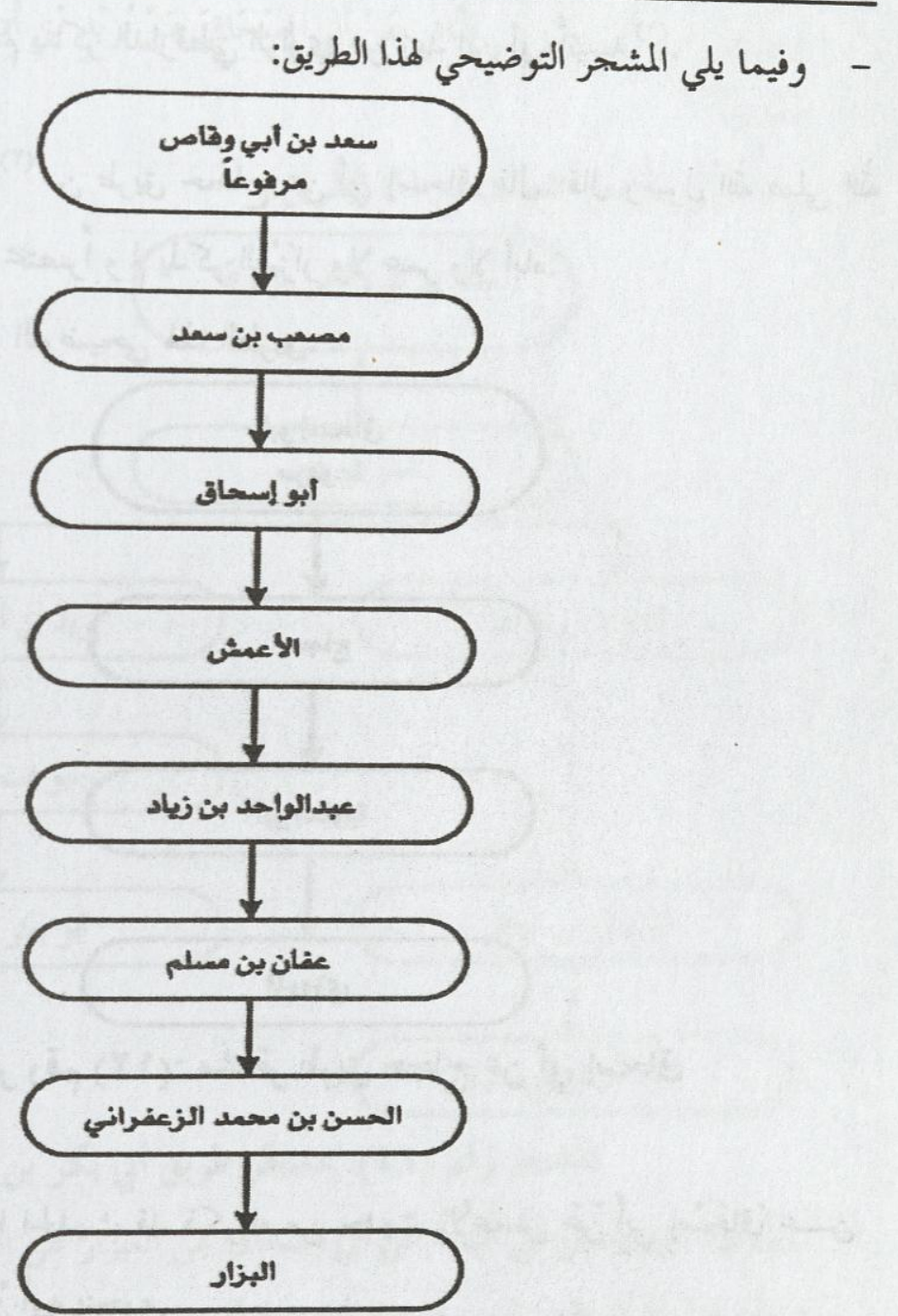

المشجو رقم (Y) (I): مشجّر طريق الأعمش عن أبي إسحاق عن مصعب بن سعد

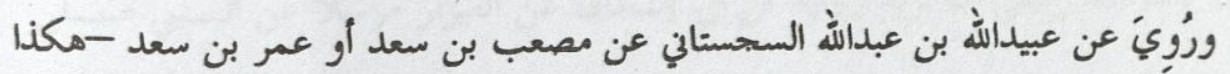

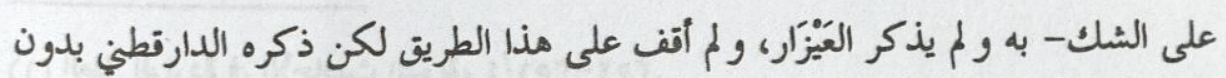
أن يذكر الراوي عن عبيدالله" (1) (1) العلل الواردة في الأحاديث النبوية، ع/Or-ror.r. $-979-$ 
سنة خمس وعشرين ومائة وله ست وثلائون سنة. ويقه ابن معين وابن سعد والعحلــي

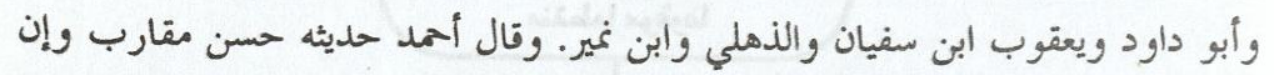

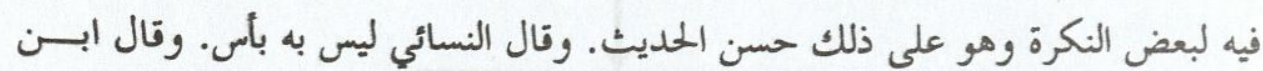

$$
\text { حجر ثقة له أفراد (1) }
$$

ورُوِيَ عن أبي إسحاق عن البني صلى الله عليه وسلم رواه عنه:

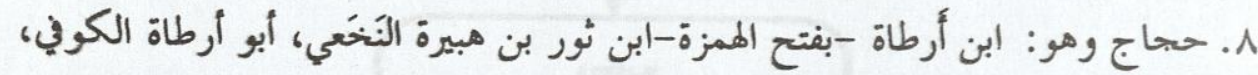

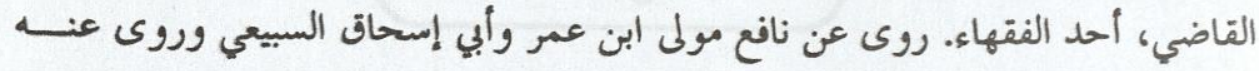

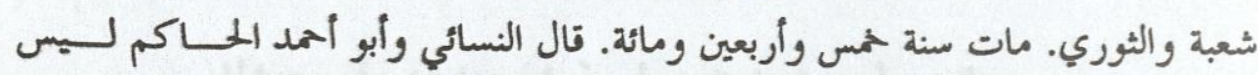

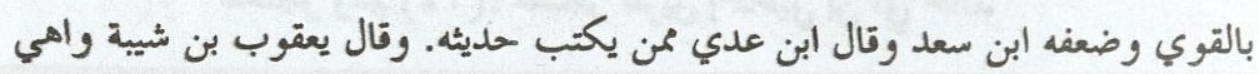

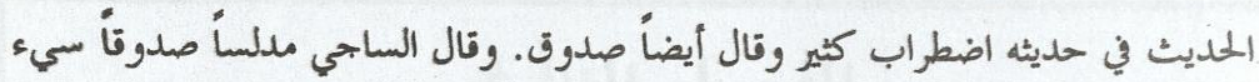

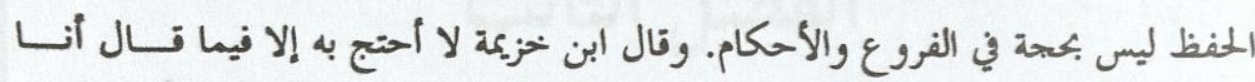

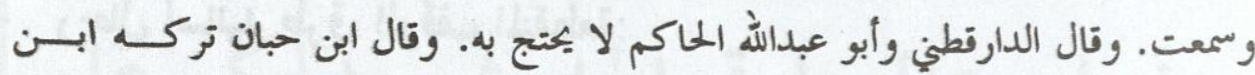

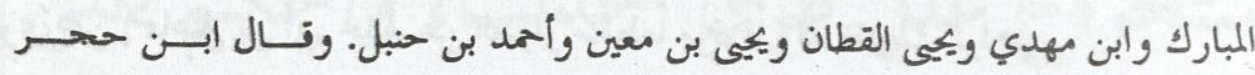

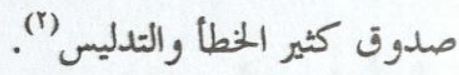

\section{ب- طرق الوقف المنقطعة:}

- أخرجه وكيع (r)عن إسماعيل بن أبي خحالد عن العَيًْار منقطعاً موقوفاً حيــث تــال العَيَْار: "أخبرت أن المؤمن... " ولم يذكر بقية السند بنحو الجزء الثاني من المتن.

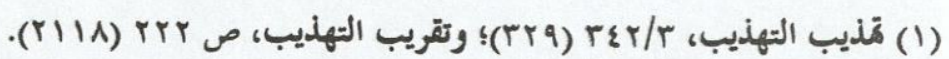

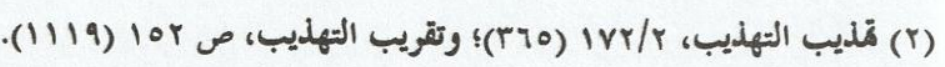

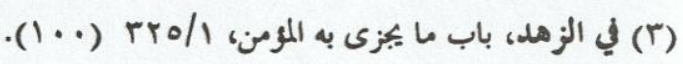

يتعمد الكذب ولعله إنما يهم في الشيء بعد الشيء. وقال ابن حجر صدوق له أوهام (1).

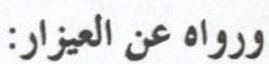
r. أبو بكر بن عياش: تقدمت تروزئه. ورواه عن بُريد بن أبي مريم:

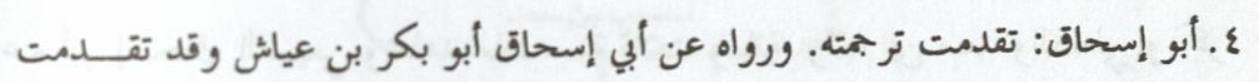
ترجمته.

ورواه عن مصعب بن سعد: أبو إسحاق وعن أبي إسحاق:

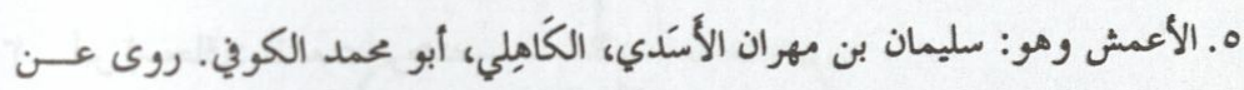
بحاهد بن جبر وعامر الشبي وروى عنه ابن المبارك وأبو إسحاق السبيعي ومن شيوخه.

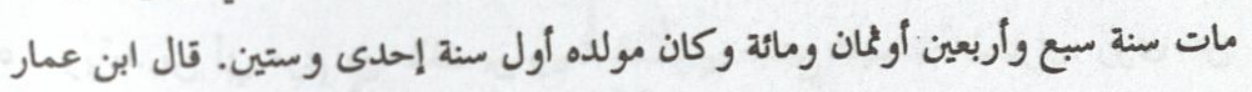
ليس في المحدثين ثبت من الأعمش ومنصور. ووثقه العحلي وابن معين والنسائي، وذكره

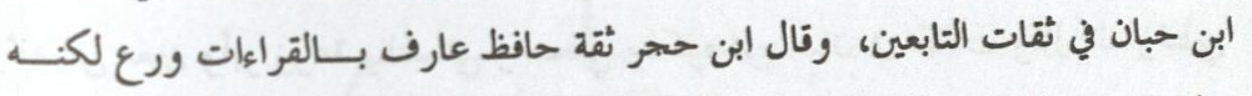
يدلس - وقد ذكر في طبقات المدلسين أنه من الطبقة الثانية(r). ورواه عن مصعب أيضاً:

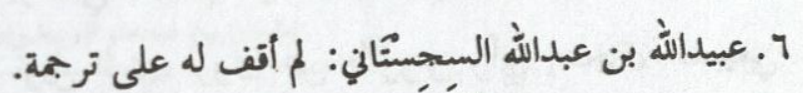

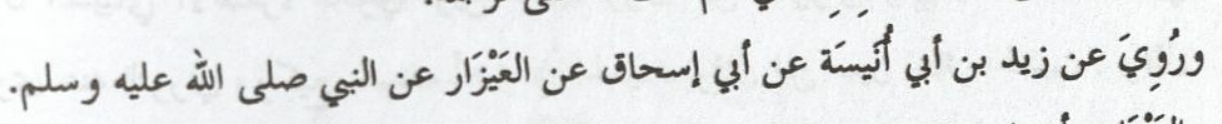

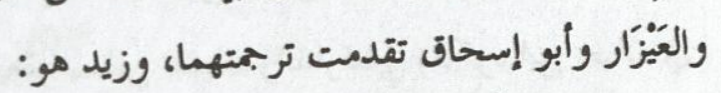

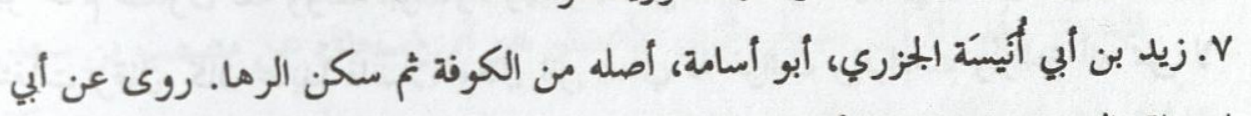

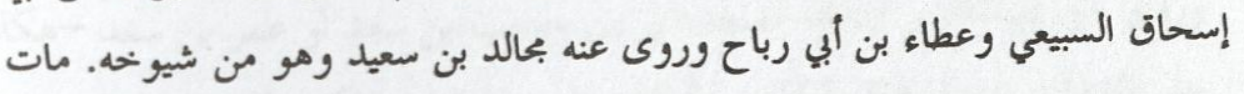

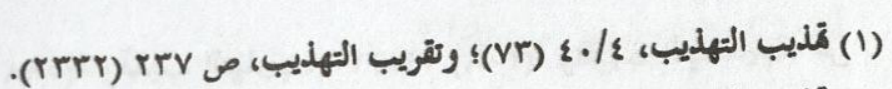

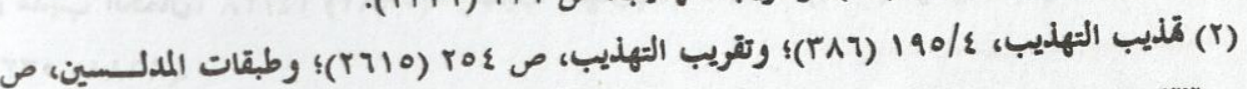


رواية سعد بن أبي وقاص رضى الله عنه لحديث: عجبت للمؤمن ...

رواية سعد بن أبي وقاص رضي الله عنه لحديث: عجبت للمؤمن ...

العيزار بن حريث

منقطعا موقوفان

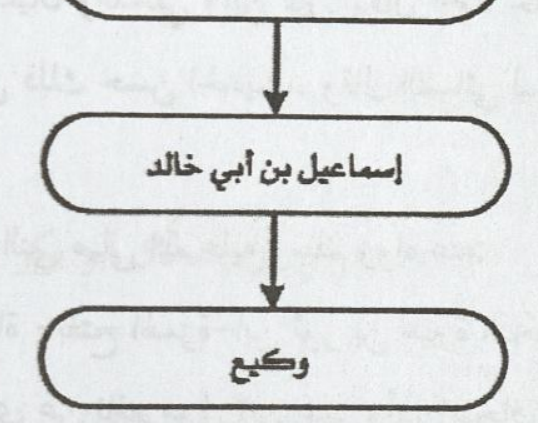

المشجر رقم (ع): مشجر طريق إبماعيل بن أبي خالد

الفصل الثالث

استخراج علل طرق الحديث، والحكم على الى الته

- - رجال أسانيد طرق الوقف المنقطعة: الحديث من وجهه الراجح بما يليق بحاله رُورِيَ عن إيماعيل بن أبي خالد عن العيزار منقطعاً موقوفاً وقد تقدمت ترابهمه. بعل الدراسة. 
وإسرائيل عن أبي إسحاق"('). لا سيما وأن الثوري أثبتُ الناس في أبي إسحاق"(r)

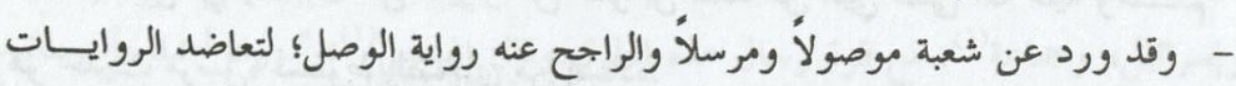

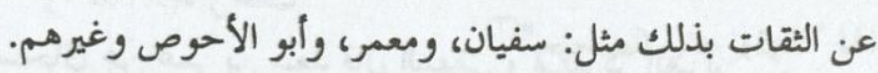

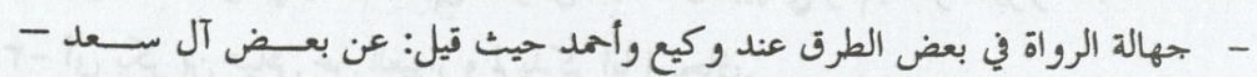

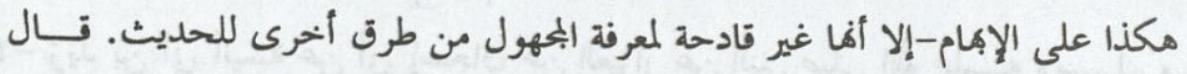

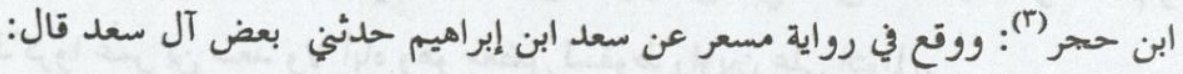

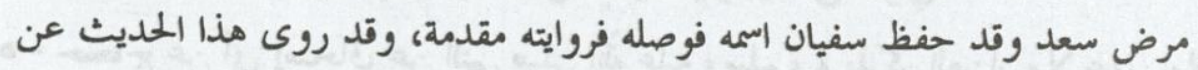

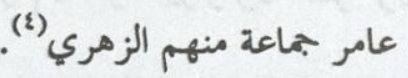
- - وفي طريق الوقف المنقطع قال العيزار أخبرت أن المؤمن فهنا تظهر جهالة من أخبره.

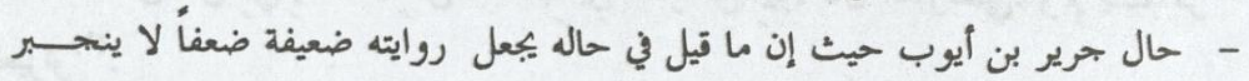

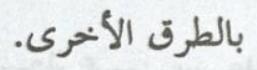

- في طريق الأعمش عن أبي إسحاق عند البزار الراوي عن الأعمش عبدالواحد بن زياد

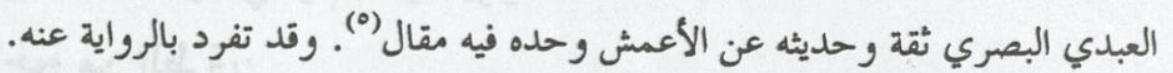
- - انقطاع الإسناد في بعض الطرق وهي:

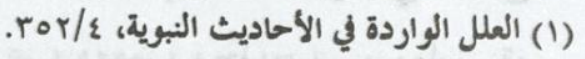

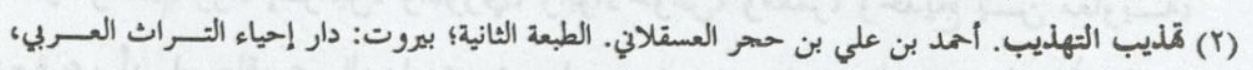

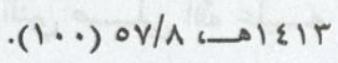

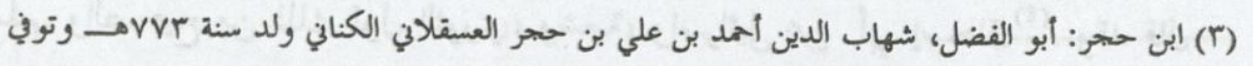

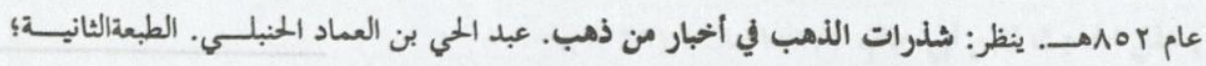

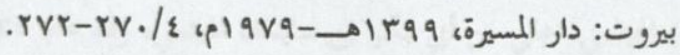

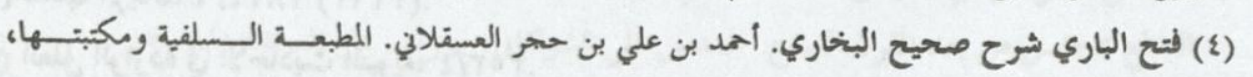

(1) الكواكب النيرات في معرفة من اختلط من الرواة الثقات. محمد بن أحمد بن يوسف أبسـو البركسـات

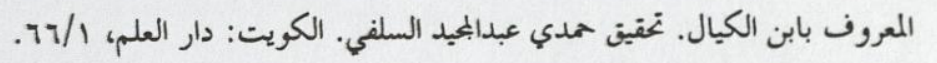

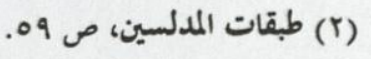

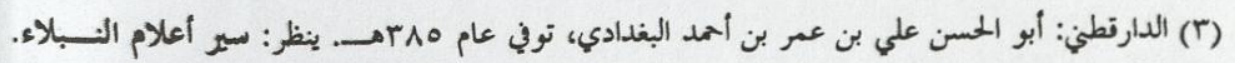

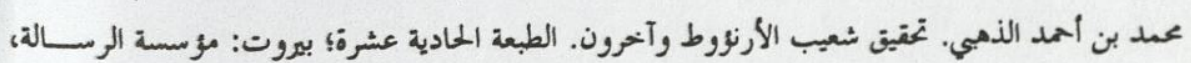

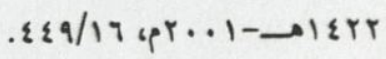




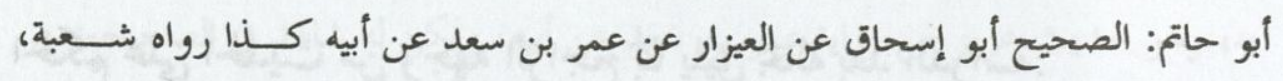

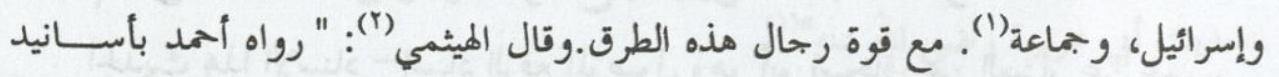
ورجالها كلها رجال الصحيح" (").

(1) علل الحديث لابن أبي حاتم،

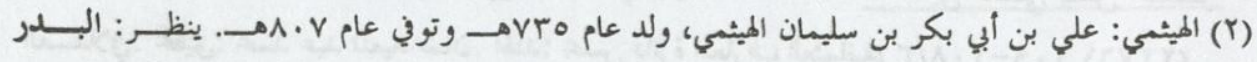

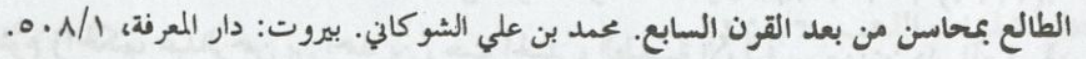

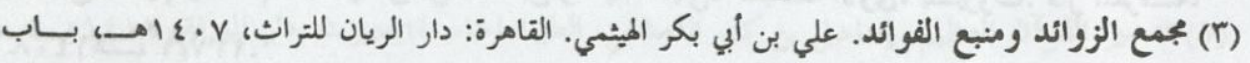

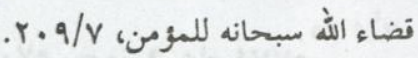

1- شعبة عن أبي إسحاق عن العيزار عن عمر بن سعد عن البي صلى الله عليه وســم وهو حديث مرسل؛ لسقوط الصحابي من إسناده.

r- أبو سنان عن أبي إسحاق عن عمر بن سعد قال البهقي و لم يذكر العيزار (1). r- أبي بكر بن عياش عن العيزار و لم يذكر أبا إسحاق.

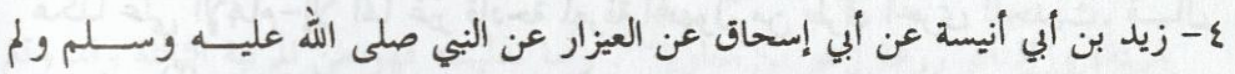
يذكروا عمر بن سعد ولا أباه وهو معضل لسقوط راويِن على التوالي.

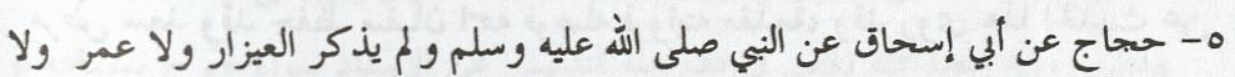
أباه.

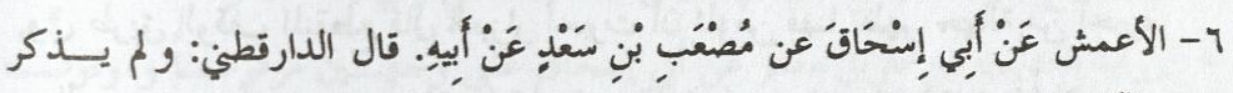

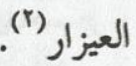
V- عبيدالله بن عبدالله السجستاني عن مصعب بن سعد أو عمر بن ســــد عــن مـــل مرفوعاً. قال الدارقطني: و لم يذكر العيزار(تالن

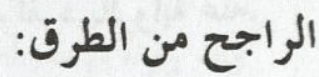

وعلى ما سبق فالطريق الراجح هو طريق الرفع الموصول بجميع رواته. قال الدار قطني

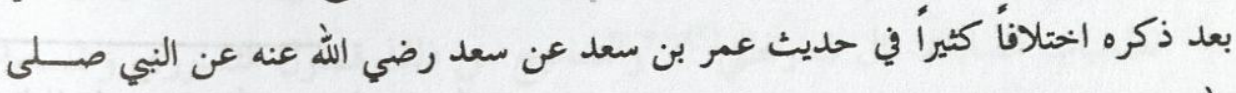

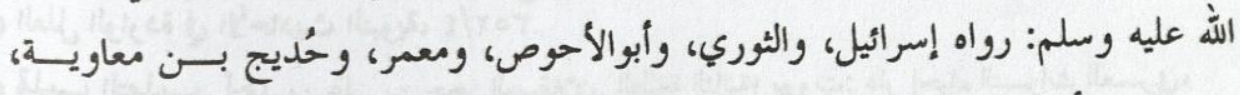

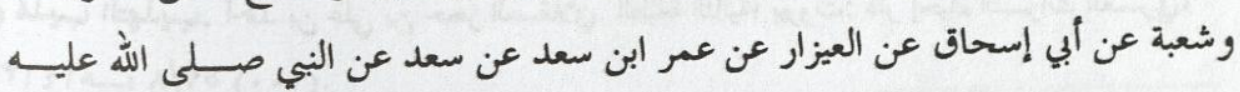

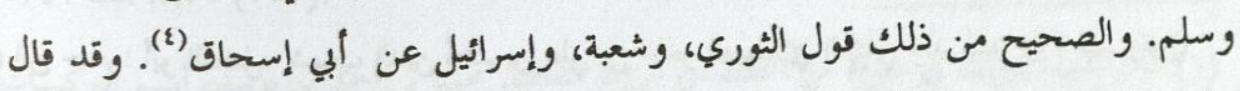

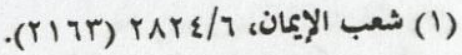

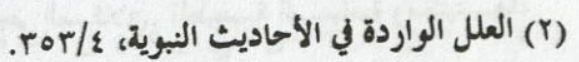

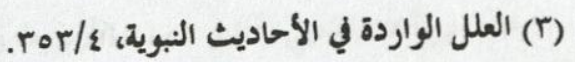

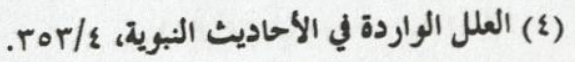


به، وهو حديث عزيز من رواية عمر بن سعد عن أبيه، ولكن له شاهد في الصحيحين من حديث أبي هريرة رضي الله عنه" (1")

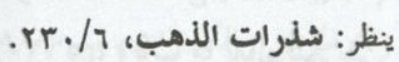

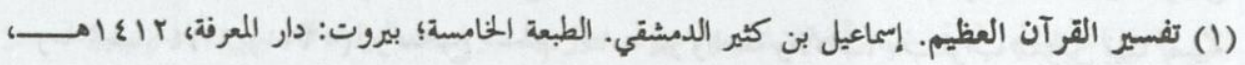
. or $7 / r$ $-7 v 8-$
الحكم على الحديث من وجهه الراجح بما يليق بكاله بعد الدراسة:

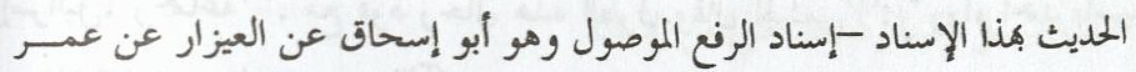

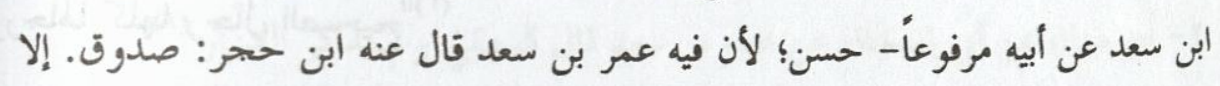

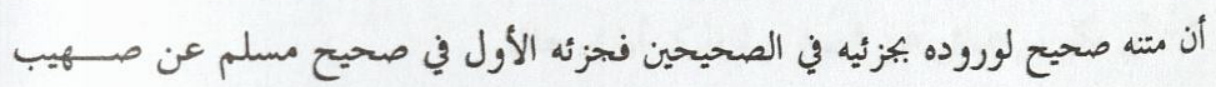

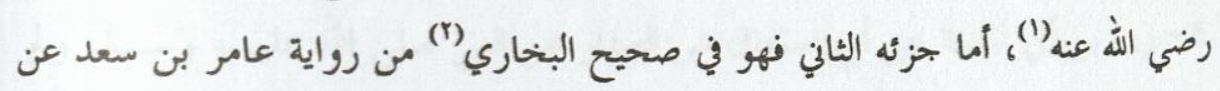
أبيه. و والله أعلم. وأما لفظ: "إلى فيه" فقال ابن رجب الحنبلي (r): "استدل بقول النبي صلى الله عليه و

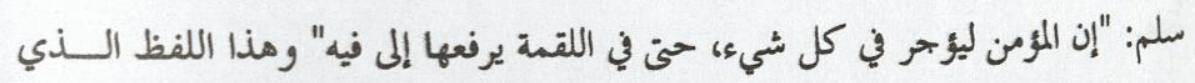

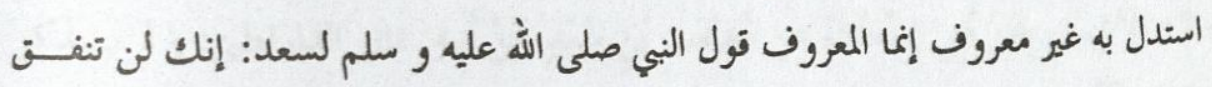

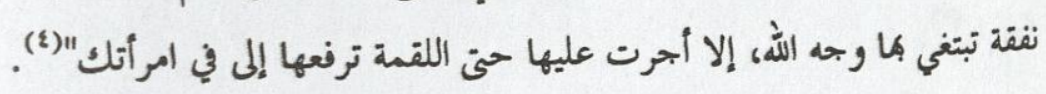

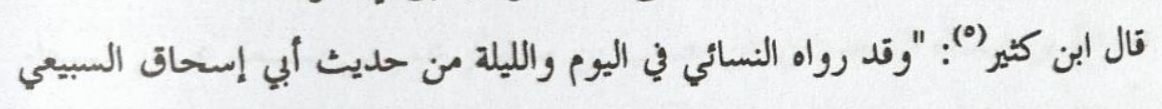

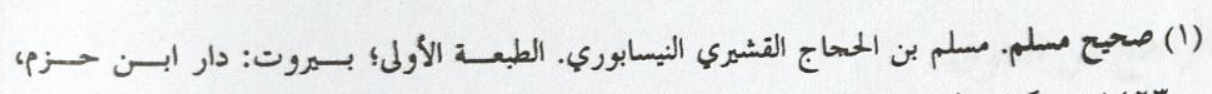

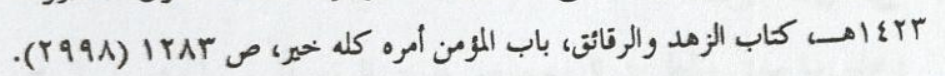

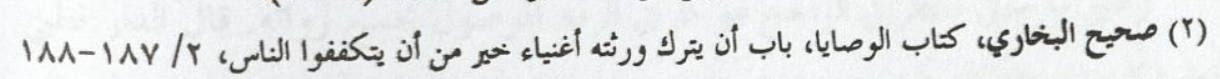

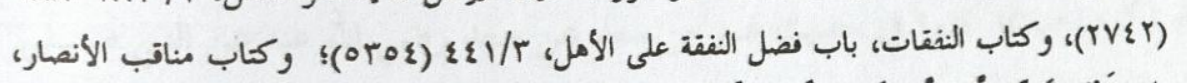

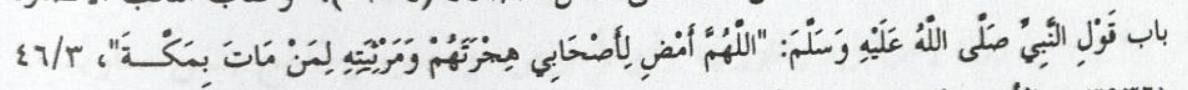

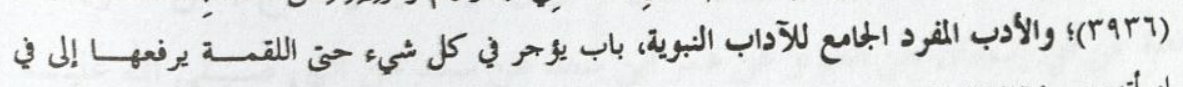

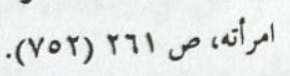

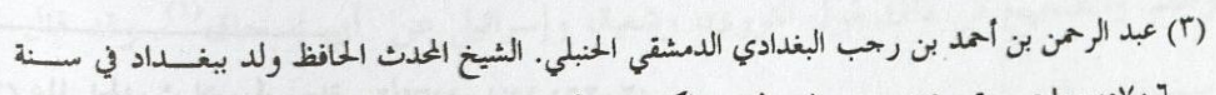

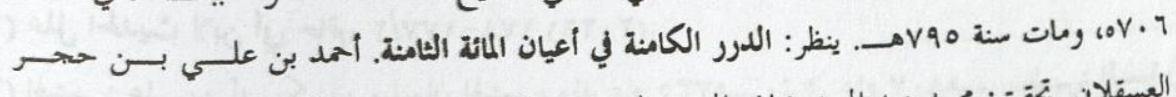

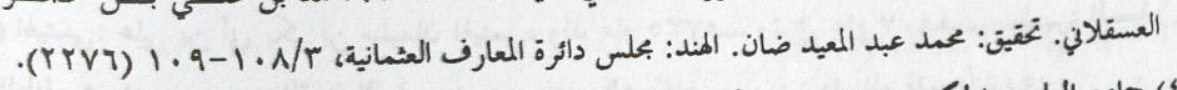

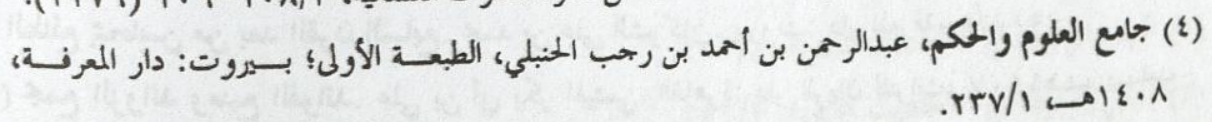

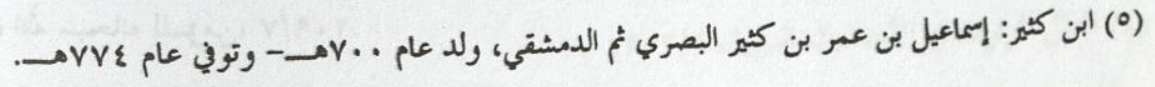
- 717 - 
والسائب ابن خلاد(1)، وأنس بن مالك(r)، وبريدة الأسلمي(")، وأبو موسى الأشعري(ع) رضي الله عنهم وغيرهم، وبعض مروياقم في الصحيحين. - ورود الحديث مقطعاً في بعض طرقيه. - لا يمكن إدراك علة الحديث إلا بيمع طرقه، والتبصر في أحوال الرواة جرحاً وتعديلاً. - قد يأتي حديث الثقة على وجه معل ويرجح عليه وجه آخر؛ للوهم من بعض الرواة إلآ في إسناده، ويظهر هذا من مقارنة الطرق وتتبعها.

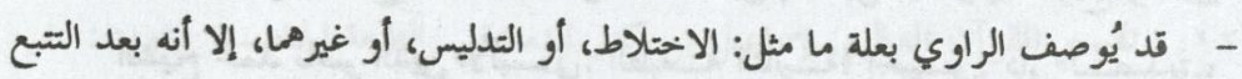
تكون هذه العلل غير مؤثرة وتُدفع بما ينفيها بواسطة جمع طرق الحديث، أو تــــريح العلماء.

- من أهم قواعد الترجيح عند الاختلاف: الترجيح بالأقوى، فإن اســتوى الــرواة في ذلك فبالاكثر، فإن استووا فبقرائن أخرى كأن تكون الرواية في الصحيحين، ونحوها.

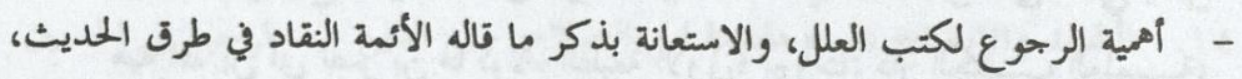
وما رجحوه وما صححوه، وما ضعفوه من تلك الطرق. - - في الأسانيد من متابعة الأقران لبعضهم مثل شعبة والثوري قرينان تابع كل منـــهما الآخر في روايته عن أبي إسحاق.

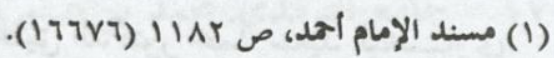

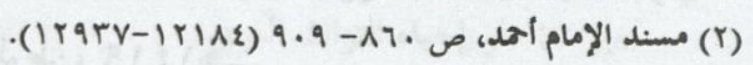

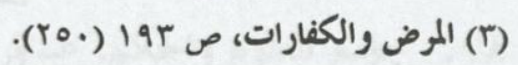

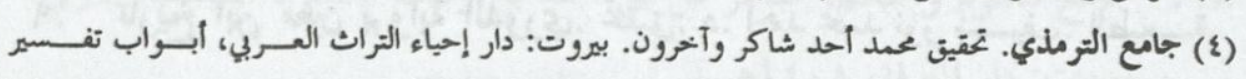

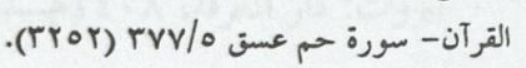
- $789-$

\section{الحاتمة}

الحمد لله رب العالمين والصلاة والسلام على نبينا محمد وعلــى آلـهـ وصـحبه أجمعين.

بعد دراسة هذا الحديث وجمع طرقه، وتخريجها، والنظر في أسانيدها ومتوفا،وبيان

غريب ألفاظه خلصت إلى النتائج التالية:

- إن هذا الحديث يُعد من ما تواتر معناه؛ حيث رُورِيَ عن بجموعة من الصحابة منهم:

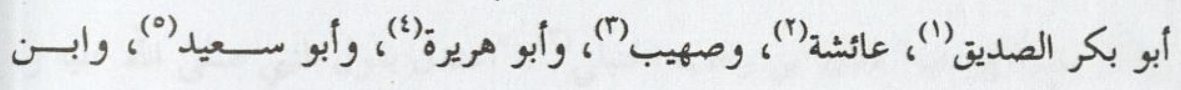

مسعود) (1)

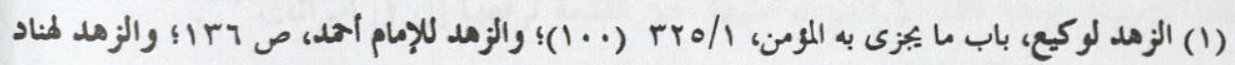

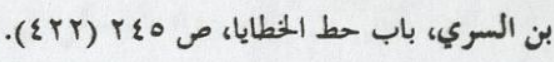

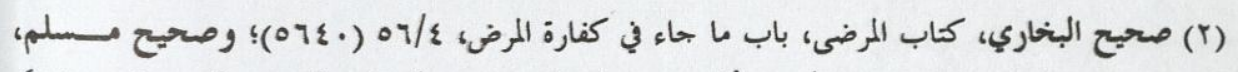

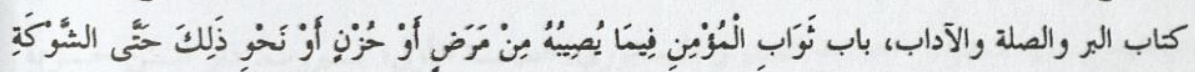

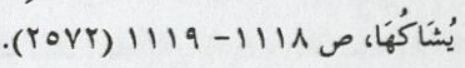

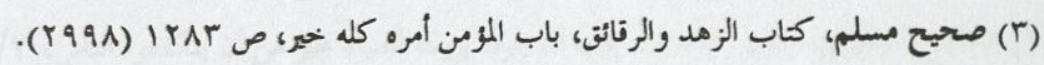

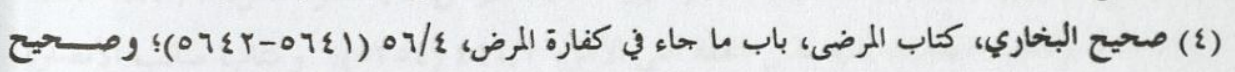

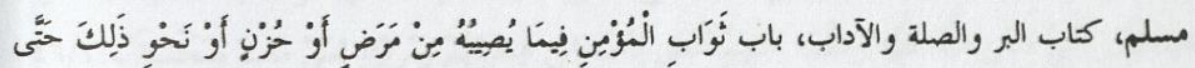
الشَّوكَة يُشَاكُهَا، ص

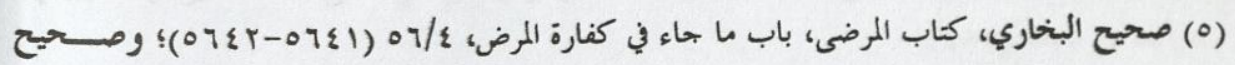

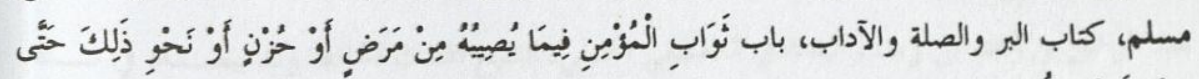

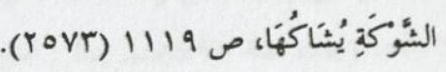

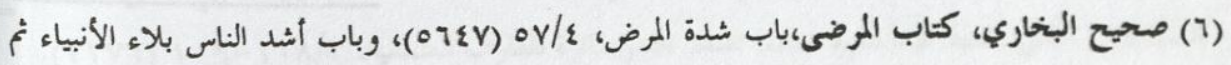

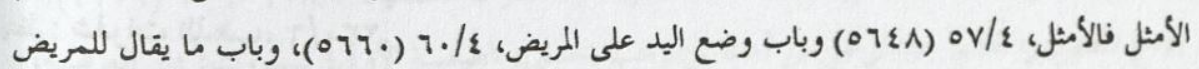

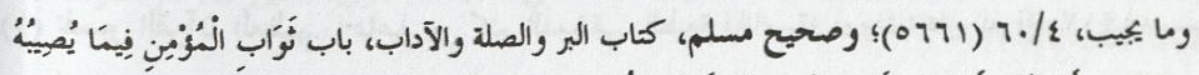

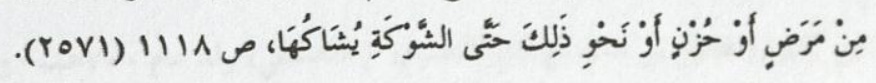


الأولى؛ مكة المكرمة: مركز البحـــث العلمــي وإحيــاء التـــراث الإســلامي، . 11799

• 1.

تحقيق: عبدالوهاب عبد اللطيف. الرياض: مكتبة الرياض الحديثة.

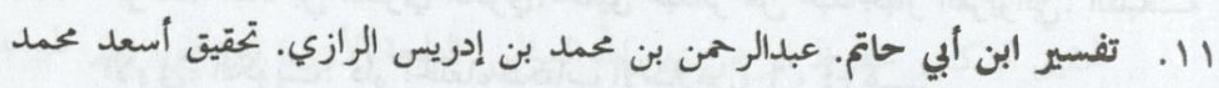

الطيب. صيدا: المكتبة العصرية.

r ا. . تفسر القرآن العظيم. إسماعيل بن كثير الدمشقي. الطبعة الخامسة؛ بيروت: دار

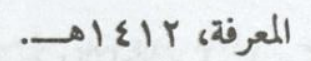
rا. تقريب التهذيب. أحمد بن علي بن حجر العسقلاني. قدَّم له دراسة وافية وقابله

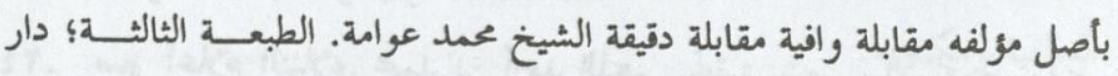

ع ا. . التقيد والإيضاح شرح مقدمة ابن الصلاح. زين الدين عبد الرحيم بن الحسين العراقي. دراسة وتحقيق: عبد الرحمن محمد عثمان. الطبعة الأولى؛ المدينة المنورة:

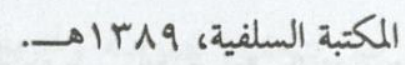
ه . مذيب التهذيب. أحمد بن علي بن حجر العسقلاني. الطبعة الثاني؛ بيروت: دار

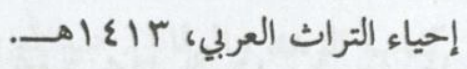

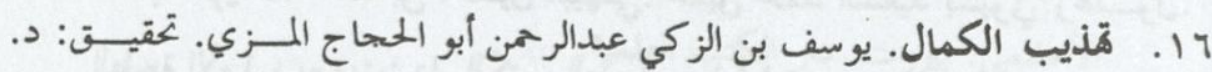

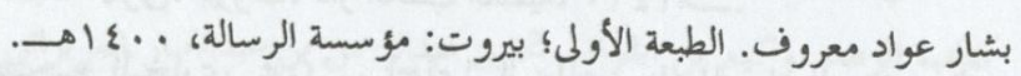
IV . . جامع الترمذي. محمد بن عيسى الترمذي. تحقيق محمد أحد شاكر وآخسـرون. بيروت: دار إحياء التراث العربي. 11. جامع العلوم والحكمم، عبدالرحمن بن أحمد بن رجب الحنبلي، الطبعـــ الأولى؛

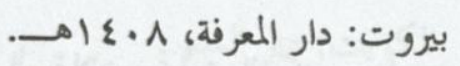

\section{قائمة المصادر والمراجع}

ا. إتحاف الحخيرة المهرة بزوائد المسانيد العشرة. البوصيري. تحقيق أبي عبد الــرحمن

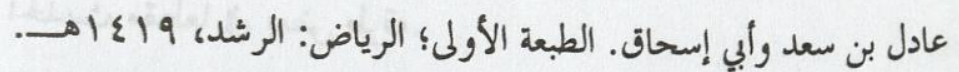

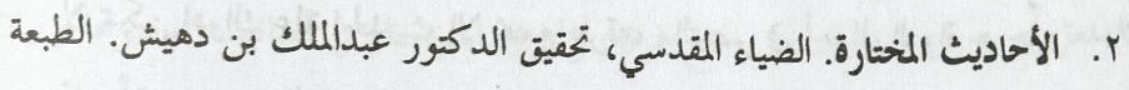

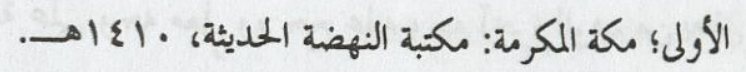

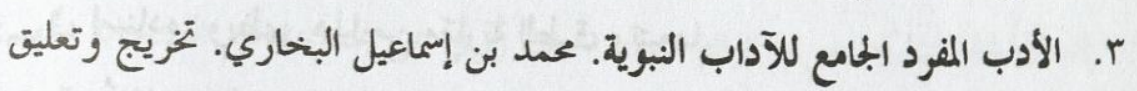

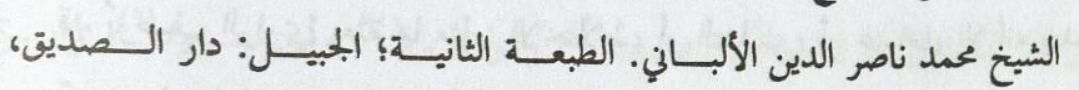

-

ع. الإصابة في تميز الصحابة. أحمد بن علي بن حجر العسقلاني. تحقيق علي محمد

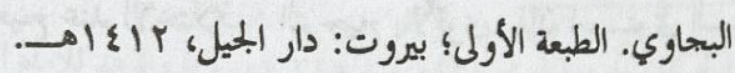

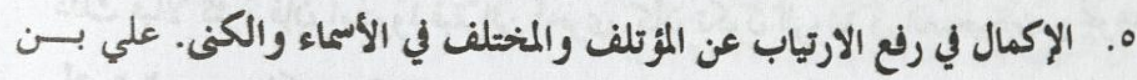

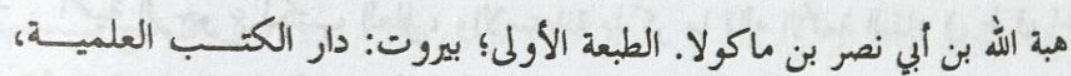
. $1 \leqslant 11$

1. . البحو الزخار المعروف بمسند البزار. أحمد بن عمرو بن عبدالحالق البزار. تحقيق

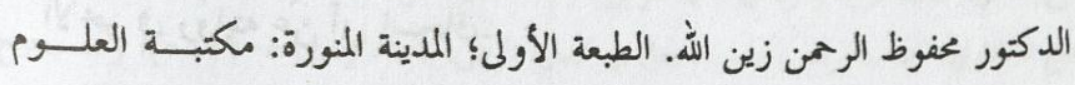
والحكم، 9 . ع 1اهـ

V. البدر الطالع بمحاسن من بعد القرن السابع. محمد بن علي الشوكاني. بيروت:

$$
\text { دار المعرفة. }
$$

^. البر والصلة. الحسين بن حرب المروزي. تحقيق الدكتور محمد سعيد البخهـاري.

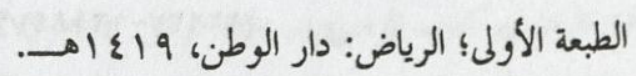

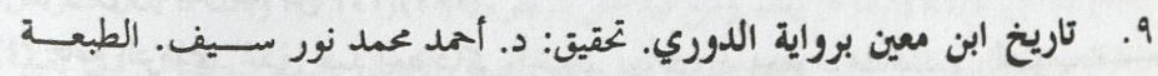


عبدالله القريوتي. الطبعة الأولى؛ الأردن: مكتبة المنار.

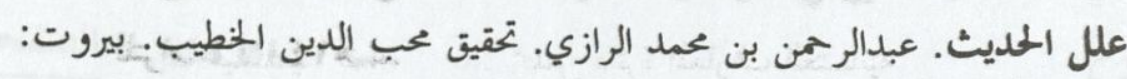

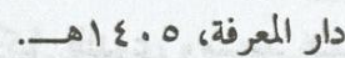
rr. العلل الواردة في الأحاديث النبوية. علي بن عمر بن أحمد بن مهدي الدارقطني.

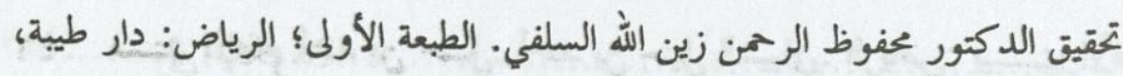

عمل اليوم والليلة. أحمد بن شعيب بن علي النسائي، تحقيق الدكتور فباروق

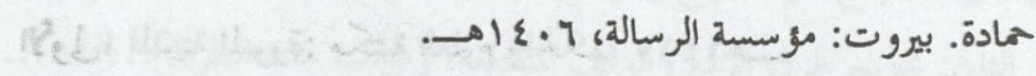
عr. فتح الباري شرح صحيح البخاري. أحمد بن علي بن ححر العسقلالني. المطبعة السلفية ومكتبتها. هr. لتح المفيث شرح ألفية الحلديث. شمس الدين محمد بن عبد الرحمن الــسخاوي.

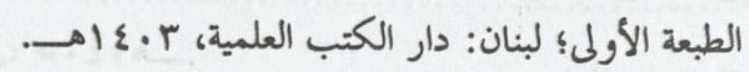
كتاب الجامع، معمر بن راشد الأزدي، مطبوع مع المصنف لعبدالرزاق الصنعاني.

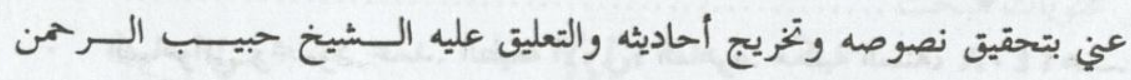

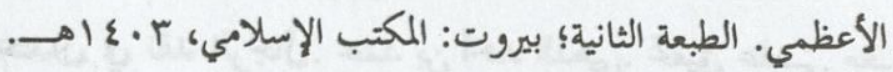
rV. كتاب الزهد والرقائق. عبدالله بن المبارك المروزي. تحقيق الشيخ حبيب الرحمن الأعظمي. بيروت: دار الكتب العلمية. كتاب الزهد. وكيع بن الجراح. تحقيق عبدالرحمن بن عبدالجبار الفريوائي. المدينة المنورة: ملكتبة الدار. وr. الكواكب الثيرات في معرفة من اختلط من الرواة الثقات. محمد بن أحمد بــن

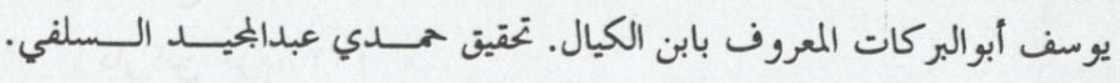
الكويت: دار العلم.
9 1. . الدرر الكامنة في أعيان المائة الثامنة. أحمد بن علي بن حجر العسقالي. تحقيق:

محمد عبدالمعيد ضان. الهند: بحلس دائرة المعارف العثمانية. •r. . . الزهد. أحمد بن حنبل الشيباني. بيروت: دار الكتب العلمية.

اr. الزهد. هناد بن السري الكوفي. تحقيق عبدالرحمن عبدالجبار الفريوائي. الطبعـة

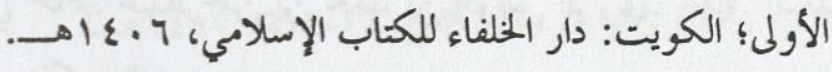

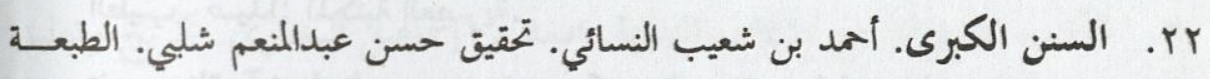

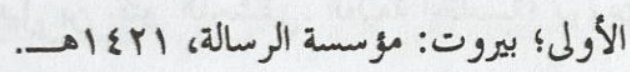

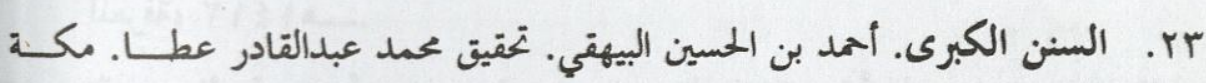

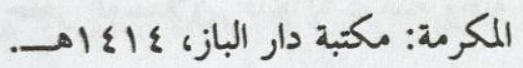
عَ. سر أعلام النبلاء. محمد بن أحمد الذهبي. تحقيق شعيب الأرنؤوط وآخــرون.

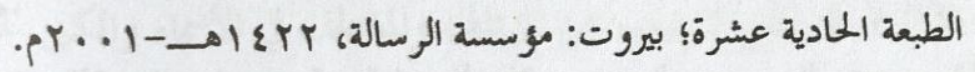
هr. شذرات الذهب في أخبار من ذهب. عبد الحي بن العماد الحنبلي. الطبعالثاني؛؛

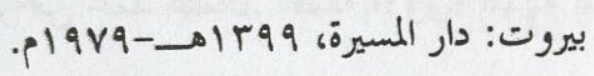
جr. شوح السنة. الحسين بن مسعود البغوي. تحقيق شعيب الأرنؤوط. الطبعة الأولى؛

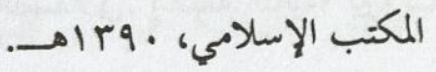
rV . . شعب الإيمان. أحمد بن الحسين البهقي. تحقيق محمد السعيد بسيوني زغلــول.

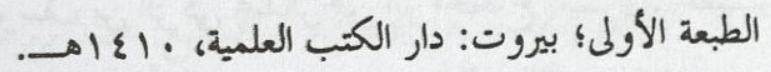

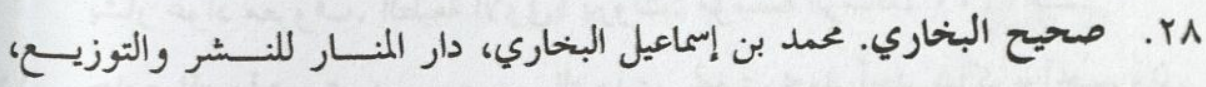
- IEYT 9r. صحيح مسلم. مسلم بن الحهاج القشيري النيسابوري. الطبعة الأولى؛ بيروت: دار ابن حزم، •r. طبقات المدلسين. أحمد بن علي بن حجر السقلالني. تحقيق الدكتور عاصم بــن - YAY- 
زواية سعد بن أبي وقاص رضي الله عنه لحديث: عجبت للمؤمن ...

\section{فهرس محتويات البحث}

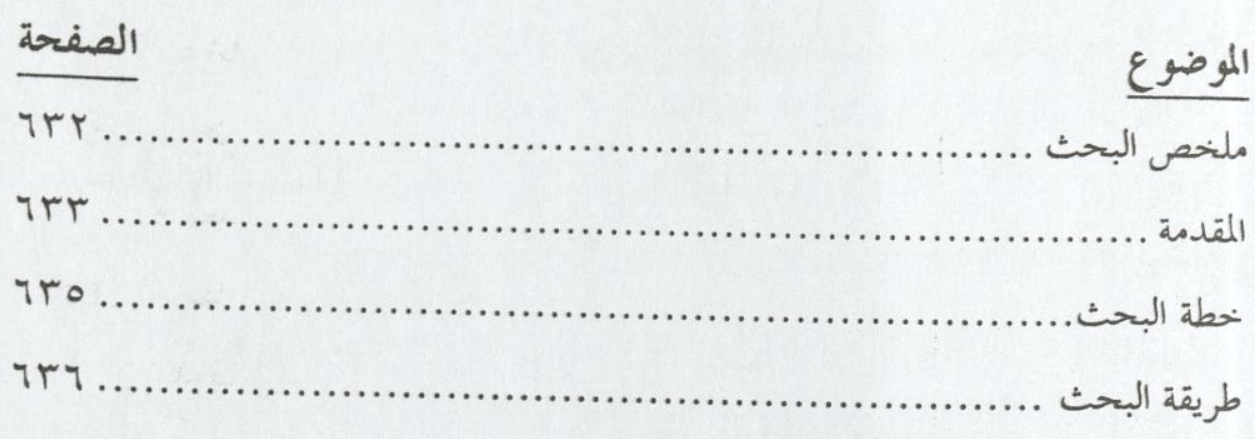

الفصل الأول: تخريج طرق الرفع والوقف الموصولة، ودراسة هذه الطرق ...............................

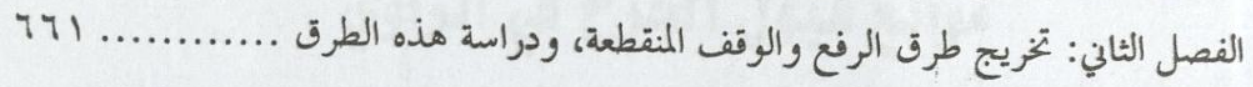
الفصل الثالث: استخراج علل طرق الحديث، والحكم على الحديث من وجهه الراجح IV) كما يليق بحاله بعد الدراسة.

TV^

$7 \wedge$ قائمة المصادر والمراجع 710 فهرس محتويات البحث
روالية سعد بن أبي وقاص رضي الله عله لطيث: عهيت للمؤن ...

•ع. مجمع الزوائد ومنبع الفوائد. علي بن أبي بكر الهيّمي. القــاهرة: دار الريــان. للتراث، V.

اع. المرض والكفارات. ابن أبي الدنيا. تحقيق عبدالوكيل الندوي ومسعد عبلالحميد السعد. بروت: دار ابن كثير، بومباي: اللار السلفية.

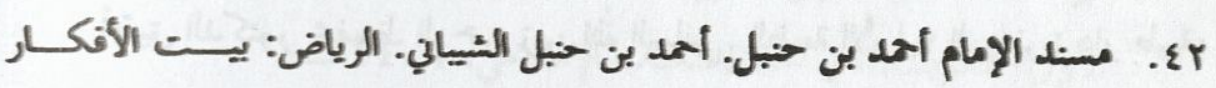

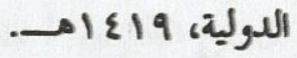

rع. مسند الشاثي. الهيثم بن كليب الشائي. تحقيق عحفوظ الرحمن زين الله. الطبعة

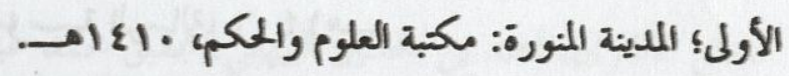
عـ. مسند الطيالسي. سليمان بن داود الطيالسي. تحقيق الدكتور عمد بن عبدائحسن التركي. دار هحر للطباعة والنشر. 0ع. المعجم الأوسط. سليمان بن أحمد الطيرالي. تحقيق طارق بن عوض الله بن محمد.

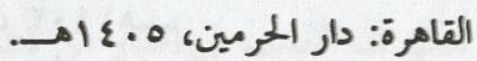
7ع. المتتخب من مسند عبد بن حميل. عبد بن حميد أبو محد الكشي. تحقيق صبحي

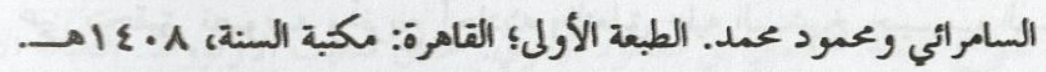

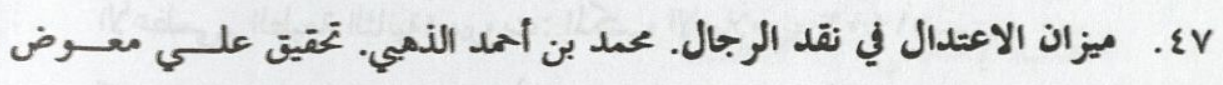
وعادل عبدالموجود. الطبعة الأولى؛ بيرت: دار الكتب العلمية، 99 ام. 